






\section{ZOOLOGICA}

SCIENTIFIC CONTRIBITTIONS OF THE NEW YORK ZOOLOGICAL SOCIETY

FROM THE TROPICAL RESEARCH

STATION IN BRITISH GUIANA

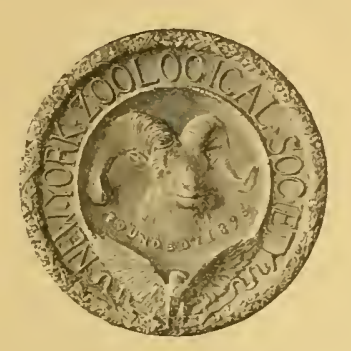

VOLUME III. NUMBER 3

(Tropical Research Station Contribution Number 97)

A STUDY OF SOME SOCIAL BEETLES IN BRITISH GUIANA AND OF THEIR RELATIONS TO THE ANT-PLANT TACHIGALIA

By William Morton Wheeler

P U B L I S H E D B Y TH E S O C I E T Y THE ZOOLOGICAL PARK, NEW YORK

DECEMBER 24, 1921

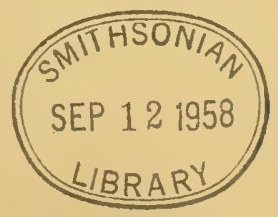


If organic evolution had stopped with insects it would still have been a succession of achievements that angels might desire to look into. The entomologist watches by the most copious fountain of wonder in the world-a well of surprises for eye and intellect.-J. ARTHUR THomson, "The System of Animate Nature," p. 545. 


\title{
A STUDY OF SOME SOCIAL BEETLES IN BRITISH GUIANA AND OF THEIR RELATIONS TO THE ANT-PLANT TACHIGALIA*
}

\author{
By William Morton WheEler
}

\section{INTRODUCTION.}

The materials for the following paper were obtained during July, August and September, 1920, while I was working with Prof. I. W. Bailey on the myrmecophytes of British Guiana. We had gone to the Tropical Laboratory of the New York Zoological Society at Kartabo for the purpose of making an intensive study of the relations of the ants to such plants as Cecropia, Triplaris, Cordia and Tococa; Prof. Bailey's investigations being primarily concerned with the anatomical peculiarities of the plants, my own with the identification and habits of their various ants. During these investigations I encountered two species of beetles of such unusual social habits that I was led to devote considerable attention to their behavior. They live in the fusiform enlargements of the petioles of a singular tree, Tachigalia, which is also inhabited by numerous species of ants. Both the beetles and the ants cultivate coccids in the hollow petioles, and with the beetles and coccids there are, moreover, several associated, parasitic or synœketic insects. And since there are also other insects, besides those already mentioned, associated with the plant, we may regard the latter as the focus of a very interesting and complicated biocoenose.

The elements of this biocoenose are so numerous and heterogeneous that I have had to appeal to several specialists for assistance in making identifications and writing descriptions. Dr. E. A. Schwarz and Mr. H. S. Barber kindly studied and described the social beetles and a little Coccinellid which feeds on their coccids. Dr. Adam Böving made a fine study of the beetle larvæ;

* Contributions from the Entomological Laboratory of the Bussey Institution, Harvard University. No. 188. 
Mr. Harold Morrison identified the coccids; the Hymenopterous and Dipterous parasites of the latter were studied by Prof. C. T. Brues and Dr. E. P. Felt. Dr. J. Bequaert, Prof. Herbert Osborn, Prof. J. W. Folsom and Dr. R. V. Chamberlin identified a wasp, two Membracids, a Collembolan and a Myriopod found living in Tachigalia petioles; and Prof. Roland Thaxter found and identified a fungus growing on the surfaces of one of the species of social beetles. I have added the reports of several of these investigators as appendices to the present paper, and wish to express my great indebtedness to all of them for their generous assistance and to Mr. Wm. Beebe for his many kindnesses to Prof. Bailey and myself while we were at Kartabo and the pains he has taken, since our return to Boston, to ascertain further facts concerning the Tachigalia and other myrmecophytes and to collect additional species of Formicidæ. So many of the ants inhabiting the Tachigalia prove to be new to science that I have had to provide a special paper for their taxonomic descriptions (Zoologica III, No. 4).

Although I have endeavored to acquire a comprehensive knowledge of the various insects associated with the Tachigalia, I am aware that my account must be very fragmentary. The territory covered was limited and in other parts of British Guiana the same tree undoubtedly harbors other insects. This is indicated by the few published observations on the trees of the genus Tachigalia and their insects in Brazil and other parts of South America. Moreover, only the leaves and petioles and their inhabitants were studied and there are probably many peculiar insects that live only in the wood and seeds or merely visit the flowers, which in some species, at least, are conspicuous and sweet-scented. The seeds were found only after they had germinated, and the trees showed no indications of flowering during our stay in British Guiana. Our inference that they might bloom during the winter months has not been confirmed, since up to the time of this writing (March, 1921), Mr. Beebe has seen no flowers on any of the trees which Prof. Bailey marked for observation. I trust, nevertheless, that my account of the Tachigalia. biocoenose will give such a picture of the astonishing complexity and exuberance of the insect fauna of the Neotropical Region, and of the fierce competition among these organisms on the one 
hand and of their intimate co-operation on the other, as to stimulate some future investigator to complete my observations. At any rate, the following pages may serve to direct the attention of our younger entomologists to one of the many wonderful, almost untouched fields for investigation in tropical America. 


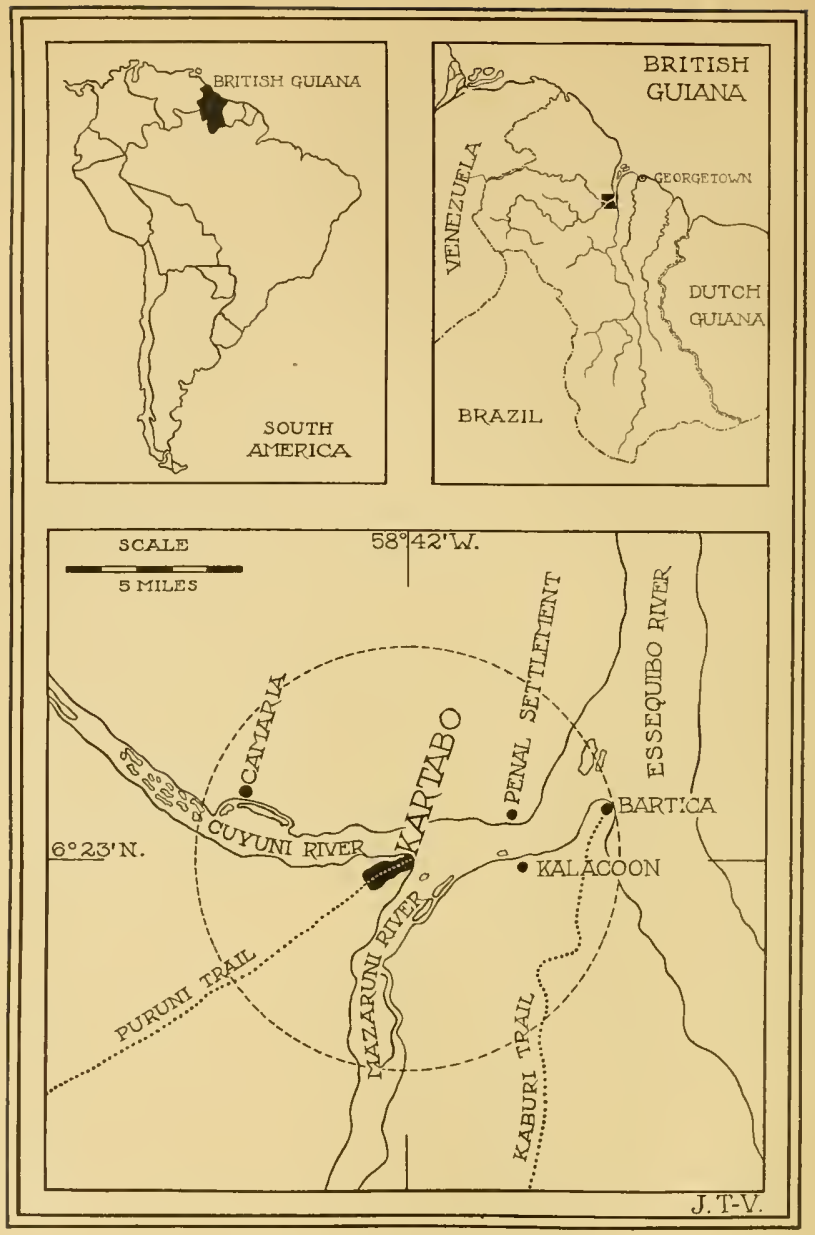

LOCATION OF THE TROPICAL RESEARCH STATION OF THE NEW YORK ZOOLOGICAL SOCIETY

The circle represents a radius of six miles. 


\section{The TAChigalia.}

The Leguminous myrmecophytes of the genus Tachigalia comprise more than a dozen known species of trees and shrubs belonging to the forest formation (hylæa) of the Guianas and the Amazon basin. The first species, paniculata, was described by Aublet as long ago as 1775 , and re-described by Tulasne in 1844. The former derived the generic name from the Carib "tachigali," "tachi" being the term employed by the natives of the Guianas and Brazil for the stinging ants of the genus Pseudomyrma, which regularly inhabit the swollen petioles of the species of Tachigalia and the hollow branches and trunk of the various species of Triplaris. Spruce (1869) was also familiar with several species of Tachigalia and their ant-inhabited petioles. Owing to our not finding the trees at Kartabo in bloom, Prof. Bailey and I have been unable as yet to ascertain their specific name. They closely resemble, however, at least in their younger stages, the species described by Harms (1906) as T. formicarum and figured by Ule (1907), who discovered it in Brazil (Plate I).

I first found the Tachigalia on the Puruni Trail near the Kartabo laboratory on July 22. The specimens were small and slender, from a foot and a half to six or seven feet tall, with only two or three to about a dozen leaves, and were growing in the shade. The petioles were inhabited either by beetles or by ants of the genera Azteca and Pseudomyrma. On the following day Prof. Bailey found what we at first took to be a different Tachigalia on the left bank of the Cuyuni River. It was a small tree, 30 to 40 feet high, with denser foliage and very different leaves. Its petioles were all inhabited by parts of a single huge colony of a yellow Pseudomyrma. Later, on finding more material, we became convinced that both trees were merely the juvenile and adult forms of the same plant, the former growing in the shade, the latter in the sun. Prof. Bailey found the seedlings in various stages and was able to ascertain that the seed is a peculiar 
samara, not a pod as in most Leguminosæ, and that the plants grow in loose colonies, the seedlings springing up in the shade about the base of the parent tree, which rises to a height of 40 to 60 feet, with a crown of foliage at the summit of a very slender trunk.

Further search revealed the fact that the Tachigalia is not uncommon in many localities within a mile of the laboratory, especially along the Puruni and Cuyuni Trails. It was also found scattered through the beautiful primeval forest at Kalacoon and Baracara on the right bank of the Mazaruni and in the jungle behind the Penal Settlement on the opposite banks of the same stream. Though the tree was often found in all the localities mentioned, it is, nevertheless, rather sporadic compared with many other components of the hylæa. It may also be very local in British Guiana and the adjacent countries. This is indicated by the fact that there seemed to be no specimens of it in the herbarium of the Botanical Garden at Georgetown nor in that of the Botanical Garden at Port of Spain, Trinidad, and neither the botanists of those institutions nor the chief of the forestry department at Georgetown had ever seen the plant. Moreover, the halfbreed Indian caretaker of the Kartabo laboratory, though familiar with it and its ant-inhabitants, did not know its native name, notwithstanding his remarkably accurate memory for the aboriginal names of most other trees of the jungle. Thus we were unable to ascertain even the generic name of the Tachigalia till we had gone over the works on the South American flora in the library of the Arnold Arboretum.

As Prof. Bailey will publish a detailed account of the anatomical peculiarities of the tree, I may here confine myself to a brief sketch of its appearance. For the purposes of this study it will be advantageous to distinguish rather sharply between the young, shade and large, sun forms, since their insect inhabitants are, as a rule, very different. In the shade form (Plate I) the Tachigalia has an extremely slender, straight trunk, from about a foot to eight or twelve feet in height, with long alternate, pinnate leaves coming off of it at right angles and at such long intervals that even the smallest of the young plants 
have only two or three, the largest hardly more than a dozen leaves. These are dark green, smooth and somewhat shining, a except at the base, where it forms a fusiform swelling two to four inches in length and a third to half an inch in diameter. The longer, more distal portion of the petiole bears six to eight pairs of broadly lanceolate leaflets, which are not drooping or pendant. The stipules at the base of the petiole are small and inconspicuous. The sun form (Fig. 4) is much more vigorous and has numerous branches at or near the summit of the long, slender, foot or less in length. The petiole (Fig. 5a) is very slender smooth, gray-barked trunk. The leaflets are pendant, more crowded, much coarser, brighter green, with more rugose surfaces and the petiole is thicker, with a large, three-cornered basal swelling more gradually continued into the leaflet-bearing portion (Fig. $5 b$ ). The cavity of the petiole also extends nearly throughout its length instead of being confined to the basal, swollen portion, and there are also cavities in the branches near each leaf. The stipules are large and conspicuous and palmately multifid. Forms of the plant intermediate between the shade and sun forms were rarely seen. The specific identity of the two forms was proved by finding young shoots of the typical shade form growing from the trunk of a large sun tree in an abandoned cassava patch at points where the wood had been cut back by the natives.

\section{The Tachigalia Biocoenose.}

The interrelationships of the various organisms constituting that portion of the Tachigalia biocoenose with which this paper deals, $i$. e., the numerous insects with their parasites and satellites, that infest the young shoots and leaves, are represented in the accompanying diagram (Plate II). It will be seen that the portion of the plant which forms what may be called the center of the biocoenose is the leaf-petiole, and it is, of course, the peculiar structure of this organ that determines the specific relations of the various insects to the host-plant and is, therefore, the key to an analysis and understanding of the whole living complex. As Prof. Bailey will publish a detailed account of the 
histological composition of the petiole, I here confine myself to a general description, dwelling only on the more salient features.

The petioles of the shade-plants are very long and slender and their enlargement is fusiform and restricted to the base, proximal to the leaftets. In cross-section (Pl. IV) the enlargement is nearly circular, with one surface, corresponding to the dorsal surface of the petiole, flattened. In the sun-plants the basal thickening passes gradually into the leaflet-bearing portion of the petiole and the cross-section (Pl. III, figs. 3 and 4) is distinctly triangular, one of the sides being dorsal, the two others forming together the inverted roof-shaped ventral portion, so that the petiole might be described as flattened dorsally and carinate ventrally. The dorsal surface is distinctly winged, or alate on each side. In the very young leaves the petiolar enlargement is solid, its interior being filled with juicy pith (Pl. III, fig. 3). This soon dries up, however, and is converted into a flocculent or fibrillar, cinnamon brown substance, lying loosely in a large cavity, the walls of which are lined by a thin layer of the same reddish tissue. The same kind of tissue, the cells of which are filled with a homogeneous amber-colored substance, is also continually forming in four longitudinal strands or rays in the dorsal wall of the petiole (Pl. IV, fig. 1). Later a few similar strands make their appearance also in the ventrolateral walls. Since the amber-colored substance which characterizes this tissue evidently has a high nutritive value, I shall call it the nutritive parenchyma. In a few petioles in this stage I found from four to six small Curculionid larvæ feeding on the loose material and reducing it to a red, powdery frass. Unfortunately these larvæ could not be reared, so that their specific identity is unknown. They are not, however, necessary agents in the preparation of the petioles for their future occupants.

As soon as the petiole has reached the stage just described it is evident that any small insect, sufficiently enterprisng to bore a hole in its wall, would find comfortable lodgings, which could easily be rendered even more comfortable by tossing the dried remnants of the pith out of the entrance or by compacting them in the narrow ends of the spindle-shaped cavity. And if the insect were a vegetable feeder it might find also an abundant food-supply in the remains of the pith still forming the lining 


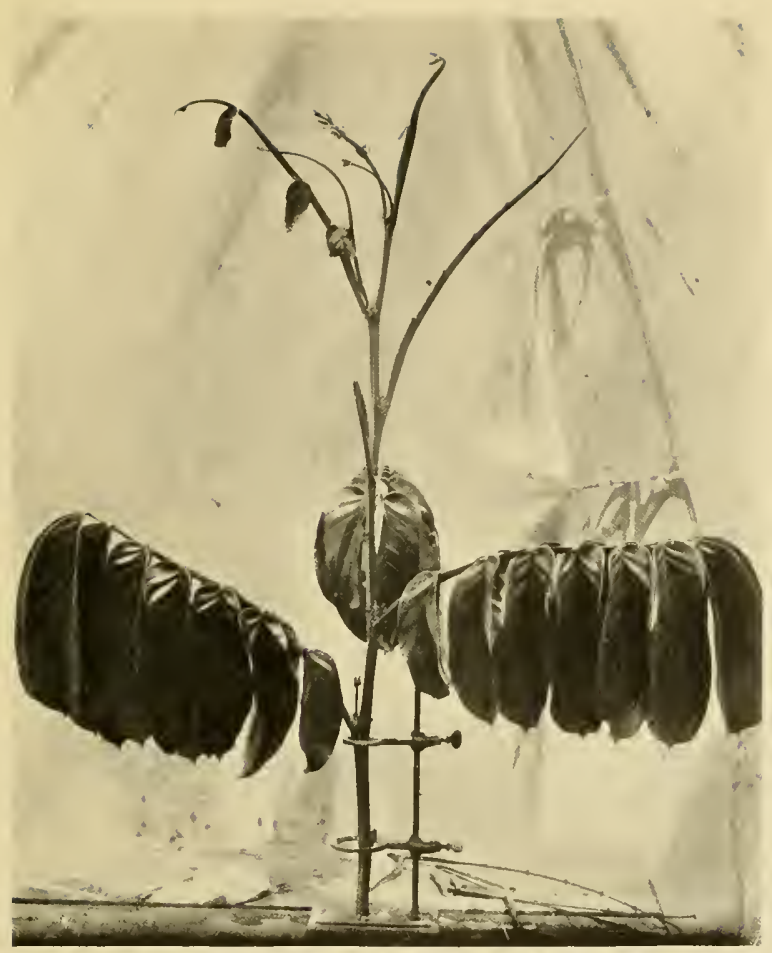

FIG, 4. BRANCH OF AN ADULT (SUN) TACHIGALIA

The leaflets have been removed from two of the petioles. Photograph by John Tee-Van. 


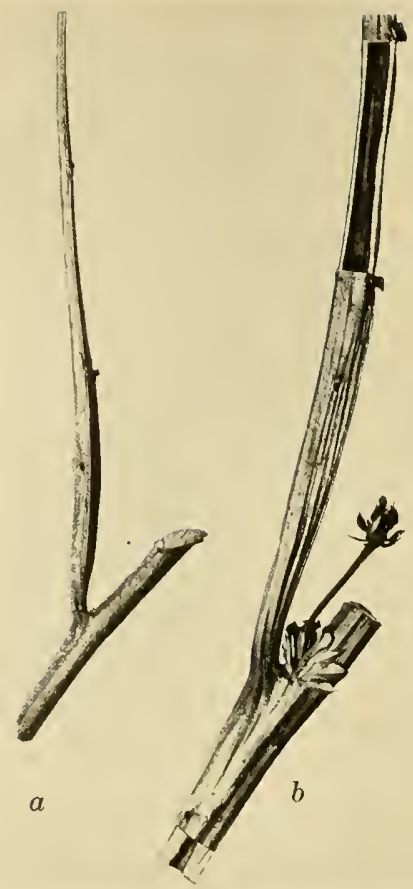

FIG. 5. BASES OF LEAF-PETIOLE OF TACHIGALIA SP.

$a$, of young, shade tree; $b$, of large, sun tree, hoth nearly $1 / 2$ natural size. Pieces of the older petiole and adjacent trunk have been cut out to show the cavity inhabited by Pseudomyrnir. 
of the cavity and especially in the rays of nutritive parenchyma. That the very exuberant neotropical fauna comprises a considerable number of such enterprising insects, the following observations will show.

It will conduce to clearness if we divide the insects which take possession of the petiolar enlargements into two series (Plate II). The first series comprises a small number of ants, social beetles and coccids which utilize all the advantages afforded by the petioles, $i$. $e$, use them not only as dwellings for themselves and their young but also as sources of food. Among these three groups of insects the coccids occupy a peculiar and important position. They are present in considerable numbers and of all sizes in all petioles inhabited by established colonies of the beetles and ants. Specimens of the coccids from petioles of both young and adult trees were submitted to Mr. Harold Morrison, who pronounces them all, without exception, to belong to a single species of mealy-bug, Pseudococcus bromeliæ Bouché (Fig. 9), a well-known form which has been taken in widely scattered tropical and subtropical localities (India, Zanzibar, Brazil, Florida and even in the hot-houses of Massachusetts) and on a variety of plants (mulberry, Canna, Hibiscus, pineapple). As these insects are, of course, quite unable to make openings in the walls of the petioles, they either wander into the cavities from the surface of the plant, after the ants and beetles have entered, or they are carried in by the former insects. Once inside the petioles the coccids attach themselves to the longitudinal strips of nutritive parenchyma in the walls, insert their beaks and find an abundant supply of sap. The ants can then absorb the saccharine excrement ("honey dew") of the coccids and thus vicariously feed on the plant. The beetles, as we shall see, not only utilize this same source of liquid nutriment but also feed on the solid nutritive parenchyma of the petiolar walls.

The other series, which comprises many more forms, merely use the petioles as nesting, dwelling or hiding places. They enter petioles that have been previously occupied and abandoned, and behave in all respects like the insects which live in old oak-galls in our northern woods. They are in fact merely tenants, or inquilines, or what German zoologists call "Raumparasiten." No coccids are found in the petioles inhabited by these insects, which 
may be divided into two groups, miscellaneous arthropods and ants. The former are probably very numerous but I have notes only on the following five:

1. In one abandoned petiole I found that a female katydid had enlarged the opening with her jaws, had thrust her ovipositor through it and had deposited her flattened eggs in the cavity.

2. On another occasion I found a petiole of a young plant inhabited by termites (Nasutitermes sp.) They had built an earthen gallery along the stem from the ground to an opening in the petiole and were living in the cavity.

3. At the Penal Settlement, near Bartica, I found in one old petiole the mature and pigmented pupa of a solitary wasp, which Dr. J. Bequaert has identified as Podium ruficrus Fabr. The mother wasp had stored the petiole with spiders, laid an egg on them and sealed up the entrance.

4. Another petiole, found near the laboratory, contained a small, red female centipede, identified by Dr. R. V. Chamberlin as Otostigmus limbatus Meinert, previously known from Brazil and Paraguay. She was coiled about her small, white, recently hatched young.

5. Some of the old and abandoned petioles on young trees were occasionally seen to be inhabited by spiders, especially by Attids.

Inasmuch as the ants comprise the more numerous and more important insects associated with the Tachigalia they may be considered in somewhat greater detail, and since their relations to the plant are of five different kinds (Plate II) they may be most conveniently grouped under as many captions.

1. Defoliators. Only one species, Atta cephalotes L., the common leaf-cutting ant of Central America and northern South America, was actually proved to defoliate young Tachigalias at a time when many of their petioles were not inhabited by other ants or inhabited only by recently fecundated queens of Pseudomyrma that had not yet produced their colonies of belligerent, stinging workers. In the jungle behind the Penal Settlement I observed a few such trees which had been either completely 
defoliated or had had large semicircular pieces bitten out of their leaflets by Atta workers. I have no doubt that these ants would carefully refrain from thus injuring larger Tachigalias in the possession of well-developed Pseudomyrma colonies. In all probability the smaller leaf-cutters of the genus Acromyrmex, not uncommon in the same locality, may also occasionally visit and defoliate the young trees, but this was not actually observed.

2. Attendants of Homoptera. The terminal shoots of young plants are often infested with a small brown Membracid in all stages (Endoastus (?) productus Osborn) and peculiar flat Membracid nymphs (probably belonging to the genus Microcentrus, according to Osborn) the piercing mouthparts of which leave on the surfaces of the petioles permanent scars that may perhaps serve later as convenient points for the beetles and queen ants to bore into the enlargements. At least four species of ants were taken in attendance on these Membracids: Camponotus femoratus Fabr., Crematogaster limata parabiotica Forel, Ectatomma tuberculatum Oliv. and Dolichoderus attelaboides Fabr. The first two were the most frequently encountered and belong to another interesting biocoenose, that of the "ant-gardens," which I have described in a recent paper (1921), the last two were of more sporadic occurrence. A few notes on their habits are recorded in Zoologica, Vol. III, No. 4.

3. Inquiline's. These comprise no less than sixteen different forms, representing thirteen species, belonging to the genera Neoponera, Leptothorax, Crematogaster, Allomerus, Solenopsis, Pheidole, Camponotus and Brachymyrmex. Most of them are small and all are timid and nonaggressive species which never keep coccids, and are more frequently found in other situations, especially in the dead twigs and branches of various shrubs and trees. And most or all of them merely take possession of petioles that have been previously perforated, inhabited and abandoned by other ants or by the social beetles. The inquiline ants, moreover, are confined to the young Tachigalias growing in the shade. Although the number of them I have collected is considerable and although they represent very diverse genera and even subfamilies, it is certain that further search, especially in other localities, will greatly increase the number, for the petiolar cavities of Tachigalia are sufficiently commodious to accomodate 
at least the young colonies of nearly all of the twig-inhabiting ants of British Guiana and the list of these is a long one, comprising many small species of Cryptocerus, Procryptocerus, Pseudomyrma, Leptothorax, Crematogaster, Azteca, Tapinoma, Myrmelachista, Camponotus, etc.

4. Thief-ants. The only species belonging to this category is the tiny Solenopsis altinodis Forel, (Fig. 15). which is closely related to a series of "lestobiotic" Solenopsis species that nest in the walls of ant-or termite-nests and prey on their brood. It does not live in the Tachigalia petioles but enters those inhabited by the social beetles, when their entrances happen to be unguarded, and destroys their larvæ. In all probability it also attacks small, defenceless colonies of the inquiline ants and devours their brood. I infer that it nests in the ground from the fact that it often appeared suddenly in considerable numbers during the night and exterminated the colonies of the Pseudomyrmas in vigorous Tachigalia and Triplaris branches that had been left on a table in the yard of the laboratory. I have also seen it wandering about on the laboratory tables indoors, over the foliage of the undergrowth in the dark jungle or feeding on the pulp of injured fruits of the water cocoa (Pachira aquatica Aubl.) growing along the river banks.

5. Obligatory Ants. I would thus designate the ants that are definitively attached to the Tachigalia as their host-tree. There are only four species: Pseudomyrma damnosa sp. nov., (Fig. 13), Ps. maligna sp. nov. (Fig. 14), with its two varieties, cholerica and crucians, Azteca foveiceps sp. nov. (Fig. 16), and A. traili Emery. The last is doubtfully included for reasons to be given below. The recently fertilized queens of these ants perforate and enter the petioles of young Tachigalias growing in the shade, close the openings behind them with particles gnawed from the walls and eventually produce their broods in the cavities. Occasionally queens of the two species of Psendomyrma or of these and $A$. foveiceps may be found, each in a petiole of the same plant and even of one with only a few leaves. That the founding of the colonies may be frought with many dangers is shown by the fact that dead queens are often found shut up in the petioles precisely as in the case of the Azteca queens in the internodes of young Cecropias. Some of the unfortunate in- 
sects undoubtedly succumb to hunger or the attacks of fungi, but in many cases they seem to be killed by alien ants or by the beetles boring into the same petioles. If the queens survive, however, and produce their broods of workers, the latter open from the inside the entrances made by the queens and eventually take possession of the whole plant. Since all the petioles of larger trees are invariably inhabited by a single flourishing colony of a single species or variety, we must suppose that the offspring of different queens on opening their respective petioles either fight for the possession of the plant or, if they belong to the same species or variety, unite to form a single polycladic colony. The fact that the petioles of large trees contain several deälated fertile females of Ps. damnosa or maligna would seem to indicate that the eventual climax colony, as it may be called, is established by alliance of several broods rather than by the survival of the offspring of a single queen. Furthermore, the climax colony seems to be far too populous to represent the offspring of a single mother.

No sooner are the petioles opened by the young broods of workers than the coccids enter or are carried in by the ants and attach themselves to the areas of nutritive parenchyma which furnish optimum conditions for feeding and growth. Here they can multiply and be cared for by the ants which undoubtedly find in them a most welcome source of food. As the tree grows and puts forth new leaves, each young petiole as soon as it has reached the proper size is perforated by a detachment of ants and coccids. The later leaves, as I have stated, have cavities extending nearly the entire length of the petioles and adjacent to their insertions there are also cavities in the branches, which are likewise entered and occupied by the insects. The largest leaves have petioles with such broad cavities at their bases that the ants find it necessary to make chambers in them by building carton partitions. The materials for the carton are gnawed from the walls. Azteca foveiceps builds a much more elaborate system of partitions than the Pseudomyrmas. This is not surprising, because the Aztecas are nearly all wonderful experts in carton construction.

When the climax stage of the Tachigalia biocoenose has been reached, it has been reduced to only three organisms, the plant, 
the coccids and Azteca foveiceps or more frequently one of the two species of Pseudomyrma or one of the varieties of $P s$. maligna. Merely rapping on the tree then reveals the situation, for the angry workers rush out of the petioles, cover the leaflets, trunk and branches and can be readily identified by their size and color, $P$ s. damnosa being yellow, A. foveiceps and Ps. maligna var. erucians black; maligna s. str. and its var. cholerica both black with yellow markings, but differing in size. Of $A$. traili only a single very young colony was seen, and this was inhabiting a petiole of a small Tachigalia. There were coccids in the cavity of the petiole, however, and both for this reason and because the ant is known to be associated with other myrmecophytes, I have included it among the obligates in the diagram. It is, in fact, conceivable that in some localities in British Guiana traili may be the dominant species and replace foveiceps in the climax stage of the biocoenose.

I have noticed unmistakable indications of two other insects on young Tachigalias, both attacking the foliage. One was a caterpillar of some kind, which had gnawed the leaflets of a few plants and had disappeared, so that I was unable to secure a specimen for identification. The other was an Itonidid gall which occurred in great numbers on a single plant on both the upper and lower surfaces of the leaflets. This gall was $2-4 \mathrm{~mm}$. long, erect and cylindrical, with a conical tip, and somewhat resembled the galls produced by Cecidomyia caryzcola Osten Sacken on the leaves of our northern hickories. The smaller galls were undeveloped and contained no larvæ but each of the larger ones had a round hole at the tip and contained in the base of its tubular cavity a cylindrical cocoon enclosing the pupa of a small parasitic Hymenopteron, evidently a Eulophid. Some of the specimens were fully pigmented and nearly ready to hatch, others had been killed by an Entomophthora-like fungus. Probably the mother of the parasite had made the round hole in the tip of the gail in order to enter and oviposit on its maker.

It will thus be seen that the Tachigalia biocoenose comprises at least 51 different organisms, the host plant and 50 organisms associated primarily with its leaves and terminal shoots or secondarily with the organisms thus associated. 


\section{The Social Beetles.}

\section{A. Coccidotrophus Socialis SCHWARZ AND Barber.}

After a careful taxonomic study of the beetles which I found in the Tachigalia petioles, Messrs. Schwarz and Barber conclude that they belong not only to perfectly distinct species but to different genera of the family Silvanidæ. While still at Kartabo I convinced myself of their specific difference, but unfortunately not till it was too late to make a detailed study of the differences in their behavior. While the species described in Zoologica III, No. 5 as Coccidotrophus socialis was so abundant that I obtained nearly four hundred of its colonies, Eunausibius wheeleri was so scarce that I encountered it in less than a dozen petioles. For some time I took it to be merely a depauperate variety or aberration of the Coccidotrophus and therefore gave it little attention. Finally, when I had come to appreciate its distinct specific status, my stay at the laboratory was drawing to a close and I could secure only a few of its colonies. My account, therefore, relates almost entirely to Coccidotrophus and my notes on Eunausibius yield only a few rather summary remarks which may be most conveniently relegated to a brief separate caption (p. 88).

The Coccidotrophus (Plate III, fig. 2; Plate VI, figs. 1-5) was taken only near Kartabo and only in the petioles of young Tachigalias growing in the shade along the Puruni, Hacka and Cuyuni trails, within a mile of the Tropical Laboratory. Although the tree was not uncommon in the jungle behind H. M. Penal Settlement and along the trails in the primeval forest near Kalacoon and Baracara, I found no traces of the beetle in these localities. It would seem, therefore, to be rather local. Its body is flattened-cylindrical, long, slender and parallel-sided, with short, stout legs, the femora, especially the fore pair, being conspicuously thickened. It varies in size from 3.5 to $4.5 \mathrm{~mm}$. and when fully mature is deep castaneous brown to almost black, with more reddish appendages. Specimens recently emerged from the pupa, however, are pale reddish testaceous, with more yellowish elytra. The surface of the body is shining and glabrous, the head and thorax punctate, the elytra punctate-striate. The head bears a singular and significant resemblance to that of certain small ants of the genus Cryptocerus. The antennæ are short, 
compactly jointed and distinctly clubbed at the tip. The female is, perhaps, somewhat smaller than the male, but I have been unable to detect any other external differences between the sexes, and Schwarz and Barber in their more careful study of the structural peculiarities of the species, have been no more successful. For further details the reader is referred to their taxonomic description in Zoologica III, No. 6.

The eggs (Fig. 11) are pure white, regularly elliptical, 0.55 long and $0.25 \mathrm{~mm}$. broad, with rather thick, leathery, smooth and shining chorion. The larva is described and figured in great detail in Dr. Böving's article (Zoologica III, No. 7, Plates VII and VIII). In life it is whitish and beautifully translucent so that the straight alimentary tract and its contents can be distinctly seen, but as maturity approaches the body becomes more opaque and milk-white, owing to a considerable increase in the fat-body. The pupa is even more opaque, but just before eclosion becomes yellowish or testaceous, with pigmented eyes. Both beetle and larva are very active and alert, the latter at all times, the former when hungry or disturbed. At other times the beetle is rather sluggish or quiescent, but shows no tendency to "feign death" when handled. Though its wings are well-developed (Plate VI, fig. 5) I have never seen it attempt to fly. The pupa (Plate IX, figs. 19-21) is also very active when stimulated, wriggling its abdomen from side to side, but is unable to move about.

The beetles enter petioles which have either not been previously perforated by other insects or those which have been occupied for some time and have then been abandoned by ants or other beetles or have been occupied by queens of Pseudomyrma or Azteca that have died before they could produce their broods of workers. The beetles either enter as a single pair or one beetle enters and is very soon joined by an individual of the opposite sex. I have been unable to decide which of these methods is followed or whether the opening in the petiole is made by the male or the female or by either indifferently. Certainly the great majority of colonies in their first, or incipient stage consist only of a male and a female beetle. On the rare occasions when only a single beetle was found in a petiole, the other may have escaped or eluded my attention while I was cutting into the cavity. Twice I have actually seen both beetles 


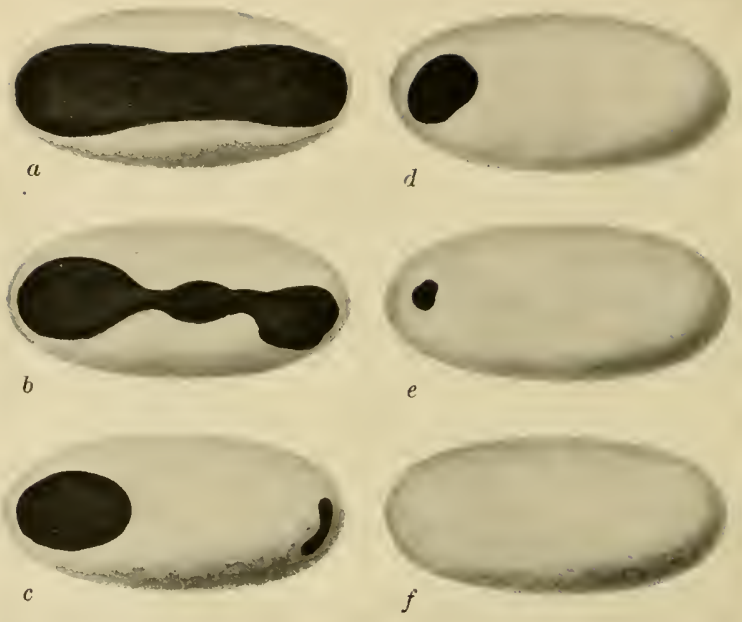

FIG. 6. SIX SUCCESSIVE STAGES IN THE CONSTRUCTION OF THE COCOON BY THE FUI,L-GROWN LARVA OF COCCIDOTROPHUS SOCIALIS. See text for explanation. 
in a cavity diligently cleaning it up for occupancy. Such housecleaning is necessary both in previously unoccupied and in previously occupied petioles since in the former the particles of fibrillar or powdery pith, which partially fill the cavity, and in the latter the dead bodies of ants, beetles, etc. must be removed. The entrance opening gnawed in the wall is transversely elliptical and just large enough to admit the slender bodies of the beetles. It is most frequently made in the lateral wall some distance from the narrow ends of the petiolar swelling. The petiole occasionally has several openings, sometimes as many as five to seven. I believe that each of these must be the work of the founders of one of the colonies which have successively occupied the same cavity. In other words, the pair of beetles seems not to utilize the openings of previous occupants for the purpose of entering the petiole but insists on making an opening of its own, so that the considerable number of orifices occasionallynoticed in an old petiole represent the number of colonies of beetles or potential colonies of ants that have from time to time taken up their abode in its cavity.

The beetles accomplish the removal of the loose pith or the remains of previous tenants by pushing this refuse into the pointed ends of the cavity with their flattened heads, much as a slovenly servant might tidy a room by sweeping things under the furniture or into closets. Smaller particles of pith are sometimes thrown out of the entrance but the decomposed and more or less disarticulated bodies of queen ants and beetles are too voluminous to be disposed of in this manner so that they can only be packed away compactly into the ends of the cavity. This behavior brings the insects into contact with the outermost layer of pith still adhering to the ligneous walls of the cavity and the strips of nutritive parenchyma laden with amber-colored substance. (Plate IV, fig. 1, Plate III, fig. 5). That this tissue actually constitutes the food of the beetles is proved not only by finding it in their intestines but also by actually observing their feeding activities. Very soon, however, young coccids begin to enter the petrole through the opening made by the beetles and take up their positions on the walls of the cavity and preferably along these very strips of nutritive tissue which, as the beetles feed, become gradually deepened into grooves. The 
coccids station themselves in a row in each groove, with the lo.ng axes of their bodies parallel with the long axis of the petiole. Since both beetles and coccids center their feeding activities on the tissue forming the floor of these grooves it is important that they shall be kept clean so that the parenchyma, which is continually proliferating, can be easily reached by both species of insects. (Plate III, fig. 5). Hence the beetles carefully deposit their feces, or frass, which has a chocolate brown color, on the areas between the grooves. As time goes on the accumulations of frass acquire the form of more or less longitudinal ridges projecting into the petiolar cavity (Plate IV, figs. 2-3 and Plate $V)$. In many petioles these ridges are strikingly regular, in others more vermiculate, interrupted or anastomosing. In old petioles inhabited by old colonies of Coccidotrophus the interior of the petiolar cavity presents the appearance of the figures on Plate $V$. In addition to these frass ridges the beetles also build a more or less circular wall of the same substance around the entrance, so that the latter is converted into a short tube, iri which one of the beetles often stations itself on guard for hours at a time, with the long axis of its body at right angles to the long axis of the petiole and its flattened head exactly filling the elliptical orifice. (Fig. 11). From time to time the beetle may project its antennæ out into the air and wave them about, so that the petiole from the outside suggests the nest of one of the smaller species of Cryptocerus, with a soldier or worker ant on guard at the orifice.

The female beetle begins to lay her eggs either before or after the entrance of the coccids. They are deposited singly along the edges of the frass ridges and evidently at intervals of several hours or even days, for dissection of the beetles shows that only a few eggs mature at a time in the ovaries. They are glued to the wall of the petiole rather firmly and always with their long axis parallel with its long axis and that of the food-grooves and frass ridges (Fig. 11). As I have not witnessed oviposition I have been unable to determine the length of the embryonic period. The eggs hateh, of course, at intervals, so that the larvæ vary greatly in size, some being very small and evidently just hatched, others a third or half-grown or actually full-grown and ready to pupate. Like the beetles, the 


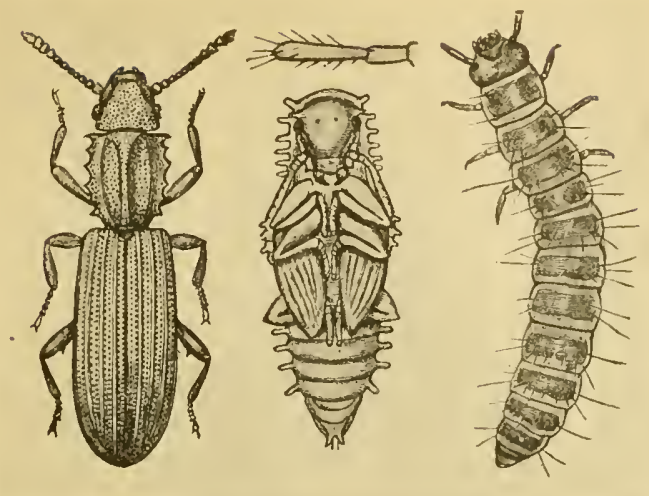

FIG 7. ORYZAEPHILUS SURINAMENSIS L

Beetle, pupa and larva, showing the teeth on the sides of the pronotum of the beetle and tubercles of the pupa in which they are formed. Courtesy of the Federal Bureau of Entomology:

larvæ feed on the nutritive parenchyma. Its amber colored cells in the intestines may be distinctly seen through the clear integument and body cavity of the larvæ. The colony, which is now in its second stage consists of the pair of parent beetles, about one or two dozen larvæ, mostly immature and in most cases of about the same number of young or half-grown coccids.

When mature the larvæ make brown cocoons and pupate in them, as will be described in detail below. These are formed singly and the beetles emerging from them remain in the petiole with their parents and larval brothers and sisters, mate and produce eggs and larvæ in turn, thus leading to the third or climax stage of the colony, which may eventually consist of several dozen beetles of both sexes and numerous larvæ and pupæ in all stages of development. The coccids also increase in number, so that the cavity of the petiole sometimes becomes so crowded that its inmates must find their movements greatly impeded. In the meantime the old and exhausted beetles gradually die off and their bodies are consigned to the refuse accumu- 

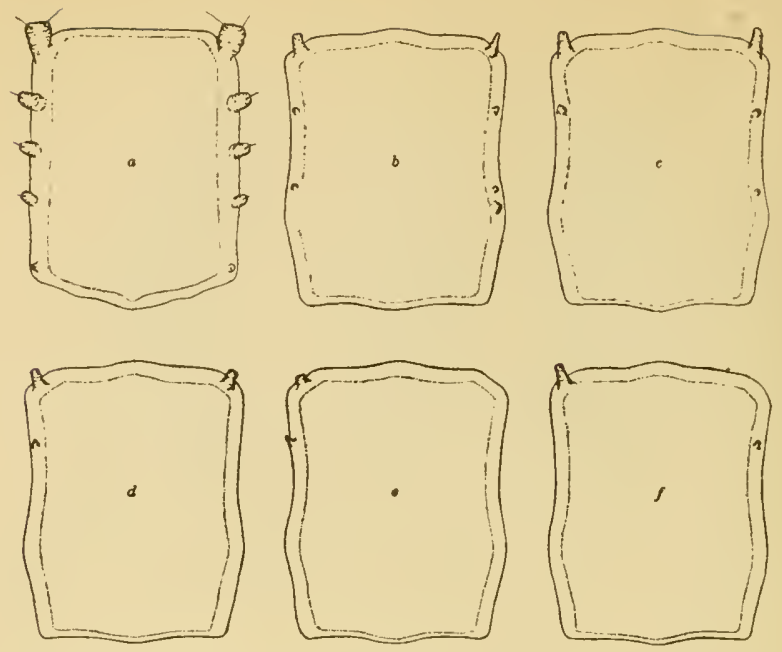

FIG. 8 .

a. pronotum of pupa of Eunausibius wheeleri showing lateral tubercles; $b$, to $f$, pronots of five pupze of Coccidotrophus socialis, showing vestigial lateral tubercles and their variation.

lations, or kitchen-middens in the pointed ends of the cavity. When this crowded condition is reached, beetles begin to leave the colony either singly or in pairs, seek and enter other petioles of the same or other Tachigalias and thus establish new colonies.

In order to study the stages of colony development just described as well as those that supervene, $I$ found it necessary to split each petiole longitudinally and to place its two halves, with their cavities turned outward in a slender vial or test-tube plugged with cotton. The cotton could be pushed in till it held the two halves firmly against the inner surface of the glass. Through the latter the behavior of the beetles could then be studied with the pocket-lens (magnifying 10-20 diameters) or the binocular dissecting microscope. Splitting the petiole, of course, so greatly disturbs the insects that many of them at once escape into the tube. Moreover, a certain number are killed or injured by the 
knife-blade. But all the uninjured soon return to the two halfcavities and remain in them. At first I carefully kept the tubes in the dark, but I soon found that they could be left in the diffuse day-light on my table without disturbing the activities of the insects. It was necessary, however, to keep them in a horizontal position, like that of the petiole on the living, plant, for when they were placed upright, gravity seriously interfered with the activities of the beetles and especially of the larvæ, causing them to drop and accumulate at the lower ends of the cavities or of the tubes. Of course, this position did not interfere with the coccids which remained attached by their sucking mouthparts to the nutritive parenchyma. Colonies of Coccidotrophus can be kept in tubes and under close observation for a week to ten days but by the fifth or sixth day the petioles are apt to become so dry even during the rainy season that the beetles, larvæ and coccids become demoralized. The modifications of behavior thus induced will be considered in the sequel.

There is, perhaps, nothing very remarkable in the fact that both the beetles and their larvæ feed on the nutritive parenchyma of the Tachigalia, since other Silvanidæ, e.g., certain species of Oryzxphilus, Silvanus, Cathartus and Nausibius are known to be vegetarian, but the fact that both the imaginal and larval Coccidotrophus actually solicit and imbibe the saccharine excrement ("honey dew") of the coccids, is so unusual and startling that it will be advisable to give a more detailed account of these insects and of their treatment by the beetles.

The adult female Pseudococcus bromelix (Fig. 9) measures nearly $3 \mathrm{~mm}$. in length and is broadly and regularly elliptical, evenly convex dorsally, flattened ventrally and of a pinkish fleshcolor or pale dull red, but the body is so completely covered with snow-white wax as to be scarcely visible in healthy specimens. The wax is secreted in a thin, even, mealy layer over the dorsal surface but around the periphery of the body as a regular fringe of stiff, blunt pencils which are longest on the posterior segments, somewhat shorter on the anterior border of the head and still shorter along the sides. Large specimens of the insect are less numerous in the petioles than the smaller or recently hatched individuals, many of which scarcely exceed $.5 \mathrm{~mm}$. in length. These are reddish because they have not yet 


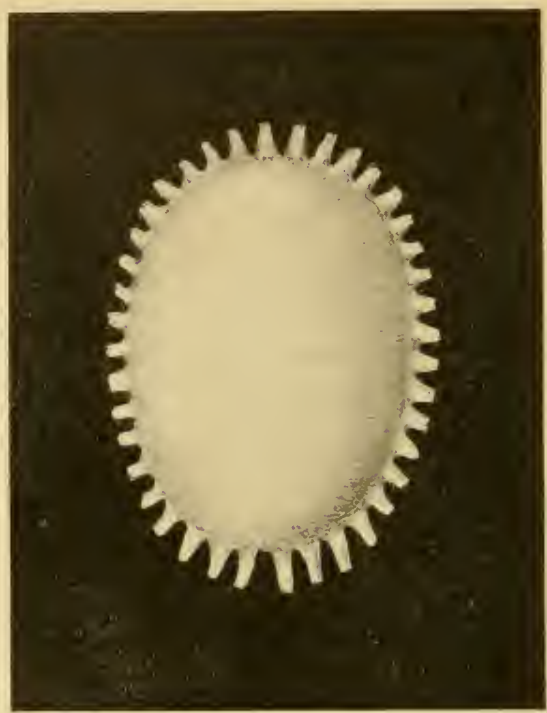

FIG. 9. PSEUDOCOCCUS BROMELIAE BOUCHE.

Sketch of an adult living female with intact covering and peripheral peneils of wax.

secreted an appreciable quantity of wax from their dorsal integument, and lack the peripheral fringe of snow-white pencils. I have not seen the males. Young individuals are rather active, not infrequently moving about in the petiole, but the older ones remain stationary in the food grooves till the peticle begins to dry up, when they take to wandering about aimlessly in search of more succulent pastures.

In specimens of the Pseudococcus treated with caustic potash and stained according to the method recommended by MacGillivray (1921, Chapter II), the details of the integument are clearly visible (Fig. 10). Only a few of the structures are of interest in connection with the following behavioristic account, such as the anus, which is on the ventral surface of the flat- 
tened posterior border of the body, and, on the dorsal surface, two pairs of peculiar organs which have the form of transverse, mouth-like slits with thick lips. One pair of these organs is situated near the posterior corners of the head, the other between the sixth and seventh abdominal segments. Coccidologists have long been familiar with these organs in certain genera of mealybugs of the subfamily Eriococcinæ, and have called them "eyelike glands" "cicatrices," "osteoliform or labiate foveæ," or "dorsal ostioles." šulc called them "adipopugnatorische Organe" and MacGillivray has recently dubbed the two pairs "cephalabiæ" and "caudalabiæ" respectively, terms so barbarous that they make one's flesh ereep. I shall call them anterior and posterior. ostioles. Berlese regarded them as apodemes, or invaginations of the integument for the insertion of muscles. Comstock, Newstead, sulc and MacGillivray regard them as glands. In 1882 Comstock stated that he had "observed in Dactylopius a pair of openings on the dorsal side of the sixth abdominal segment, which are evidently homologous with the honey tubes of Aphididæ. A female mealy-bug was gently rubbed near the caudal end of the body, when suddenly there appeared two drops of a clear fluid, resembling in appearance the honey-dew of plantlice. This experiment was repeated many times and with many specimens. Mr. Pergande assures me that he has observed a similar excretion from a pair of openings on the cephalic margin of the first thoracic segment." Comstock was, of course, under the erroneous impression that the honey-dew of aphids is a secretion of the cornicles instead of being the excrement of the insects and therefore extruded from the anus. According to MacGillivray: "There can frequently be observed on living specimens a small globule of a clear fluid over the mouth of each labia, more frequently the caudalabiæ than the cephalabiæ, so that they are probably also glandular in structure as suggested by Comstock. For, as he suggested, when the specimens are stroked with a pencil or dissecting needle, the insect will hump up its back and extrude a globule of liquid. The insect is unable to repeat this operation until the pocket is again filled with the clear fluid. Specimens have been observed to extrude globules from all four labiæ at the same time. The labiæ undoubtedly have a glandular function wlich is probably of later origin than their earlier function, a parademe for the attachment of muscles." 


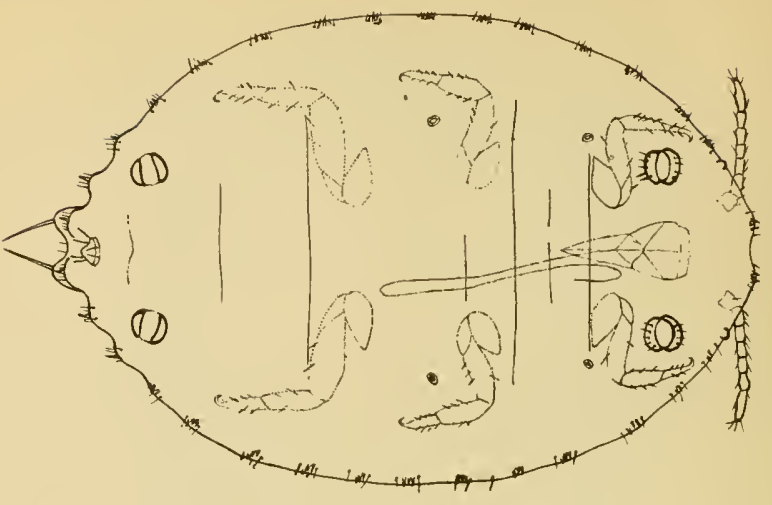

FIG. 10. PSEUDOCOCCUS BROMELIAE BOUCHE.

Adult female treated with caustic potash to show the openings of the anterior and posterior ostioles, anal orifice, etc.

The specimen is mounted dorsal surface uppermost.

sulc (1909) made a histological and physiological study of the anterior and posterior ostioles in Pseudococcus farinosus De Geer. When the female of this insect was stroked with a brush, each of the ostioles suddenly emitted a droplet of orange-yellow liquid, which partly adhered to the brush and partly rolled off from the wax-powdered dorsal surface. The liquid was found to consist of cells and a few blood-corpuscles. sulc concludes that the organs are repugnatorial, and that their secretion is employed like that of the cornicles of aphids for gluing up the appendages of insect enemies. His account of the function of the secretion is by no means convincing, since it might also be regarded as an exudate, derived directly from the fat-body, like the exudates produced by various termitophiles and myrmecophiles ( $C f$. Wheeler 1918), and hence employed for allurement instead of repulsion.

Returning to a consideration of the Coccidotrophus in the Tachigalia petioles, we find that the beetle often remains motionless for hours at a time, in a food-groove, which just fits its long slender body. If at other times, when it is moving about, it 
chances upon a coccid, it stops suddenly and seems at once to become more alert or excited, for as soon as its clubbed antennæ touch the dorsal surface of the insect, their beat, hitherto leisurely and exploratory, becomes greatly accelerated. With each beat, each antenna rapidly describes a minute transverse ellipse on the surface of the coccid, and the beats of the two appendages seem not to be quite synchronous. At the same time the beetle, with a much slower rhythm, rocks its body forward and backward by bending its legs, while the mobile articulations between the head and prothorax and between the prothorax and mesothorax enable it to cover more of the coccid's dorsum and to keep the antennal clubs in contact with its rounded surface. While engaged in this perfomance the beetle resembles an expert pianist moving his hands from side to side over the key-board, or a masseur with his hands in soft gloves, massaging a patient. The beetle undoubtedly distinguishes a large coccid's posterior from its anterior end, since it lavishes most attention on the former. It seems, however, to be quite as interested in the medium-sized or smallest coccids and will spend just as much time in stroking them. The time devoted to the performance in any particular case seems to vary directly with the beetle's appetite or thirst. A beetle may thus spend ten, twenty or even forty or more minutes massaging a single coccid, with occasional short pauses. After a coccid in the proper condition has been stroked in this manner for a few moments it may slowly turn up its wax-penciled posterior segments and discharge from the anal orifice a perfectly limpid droplet of sweet excrement, which the beetle at once greedily swallows. The coccid then flattens down its posterior segments and the beetle resumes its massage. The coccid may thus contribute a droplet every few minutes or it may remain inert and unresponsive. An ant confronted with such a situation would take the hint and at once look up another coccid, but the beetle stubbornly keeps on and may work for an hour or more without receiving another drink. Usually, however, some of the larvæ or one of the other beetles of the colony intervene and the scene may change, as described in a later paragraph.

That the antennæ of the beetle are beautifully adapted for stroking the coccids is apparent at a glance (Plate III, fig. 2, 
Plate VI, fig. 1). Their compact structure and clubbed extremities recall the antennæ of many myrmecophilous beetles or of certain ants, for many of these insects, of course, use their antennæ in soliciting liquid food from one another. The basal joint of the Coccidotrophus antenna is even elongated to form a crude scape, although the remaining joints do not form an anglc with it as in ants. The relations of the beetle to the coccids, moreover, are physiologically similar to those of symphilic beetles to the host ants that feed them with regurgitated liquids, and the Coccidotrophus like the symphiles has a short, broad tongue and short labial palpi. Wasmann (1896) and Escherich (1902) have dealt with these antennal and labial adaptations in detail, pointing out that the tongue in symphilic beetles becomes short. broad and spoon-like and that the palpi, especially those of the labium, become shorter and have a reduced number of joints. Precisely this condition is seen in the labium of Coccidotrophus as shown in the figure of Schwarz and Barber (Pl. VI, fig. 1). The greater development of the maxillary palpi indicates that they may occasionally function like the antennæ in soliciting honey-dew.

Coccidotrophus larvæ of all stages, from those just hatched and less than a millimeter in length, to those almost four millimeters long and nearly ready to pupate, likewise solicit and obtain food from the coccids by stroking them with the antennæ. The small beetle larvæ show no preference for small coccids since just hatched larvæ are often seen on the backs of adult female coccids, feverishly stroking their waxen surfaces and full grown larvæ may often devote themselves to coccids smaller than their heads. The movements of the larva's antennæ, though similar to the antennal strokes of the beetles, cover a smaller portion of the coccid but the larvæ reinforce the titillation by a simultaneous use of the maxillæ and maxillary palpi. The larva is almost or quite as persistent as the beetle and drinks up the periodic globules of honey-dew with quite as much gusto. Both beetles and larvæ, however, stroke the dorsal surfaces of the coccids so gently that their waxen bloom is neither removed nor diminished even after the most prolonged solicitations.

In connection with the behavior of the larva, Dr. Böving's figures of its mouthparts and antennæ are very interesting and 


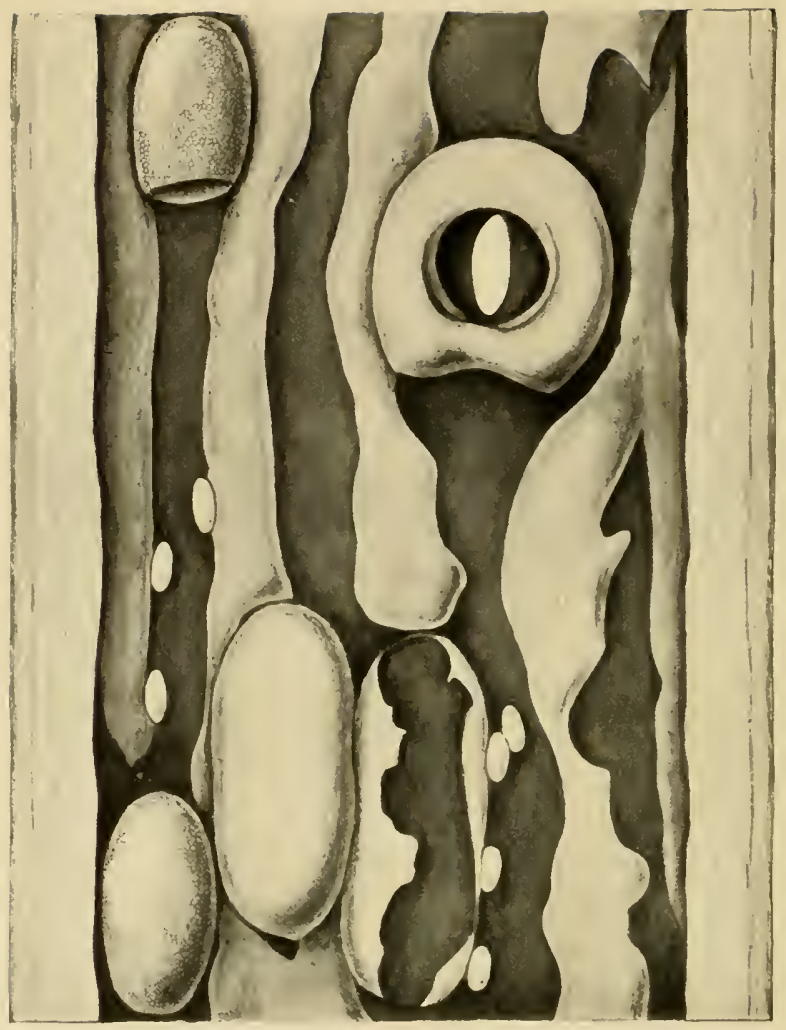

FIG. 11. ENLARGED DRAWING OF A PART OF THE WALL OF A TACHIGALIA PETIOLE INHABITED BY COCCIDOTROPHUS SOCIALIS.

Showing the food grooves and frass ridges, the entrance with its wall, the eggs, an intact and broken cocoon of the Coccidotrophus and two cocoons of Blepyrus tachigaliae, one of them after the eclosion of the parasite. 
suggestive. It will be noticed that his Figs. 1, 2, 5, 8, 16, Plates VII and VIII etc. show that the tongue is large and flat like a spatula or ladle and well-adapted for receiving the globules of coccid excrement. The labial palpi are very small and 2-jointed, but the maxilla is large, with extensive stipital articulation and a large lacinia tipped with a claw-like tooth and fringed with stiff hairs along the medial border. The maxillary palpi are long and 3-jointed and the large articular membranes of the separate joints suggest great mobility. The antennæ are unusually interesting (Plate VII, figs. 1, 2, 5, 7). Though they consist of only three joints, the second is greatly elongated and distinctly drum-stick-shaped, the apical joint being much reduced to form merely a sensory cap for the second joint. Now this drum-stick-type of antenna is precisely the one found in a long series of symphilic ant-guests of the Coleopterous family Clavigeridæ (Fustiger, Rhynchoclaviger, Adranes, etc.), which use their antennæ for soliciting liquid food from their hosts. Dr. Böving's figures of other larval Silvanids and of genera belonging to closely allied genera of the Cucujid complex, namely Cathartus (Plate VIII, fig. 12), Nausibius (Plate VIII, fig. 18), Dryocera (Plate IX, fig. 33), Telephanus (Plate X, figs. 34, 37) and Scalidia (Plate $\mathrm{X}$, fig. 39), show very different conditions. Thus we may say that the antennæ and maxillæ of the Coccidotrophus larva are specially adapted to their active rôle of soliciting and the labium to its passive, spoon-like rôle of receiving the liquid excreta of the Pseudococcus.

The question naturally arises as to the function of the anterior and posterior ostioles, which, as I have shown, are highly developed in Ps. bromelix, and the probability of their secreting substances that may be ingested by the beetles. Unfortunately I did not know of the existence of the ostioles while I was at Kartabo. My attention was called to them by Prof. Mac Gillivray several months after my return. I feel very confident, nevertheless, that these organs in Ps. bromelix cannot have the function ascribed to them by sulc in $P_{s}$. farinosus. I have so carefully watched the coccids of all ages that I could not have overlooked the emission of orange-yellow droplets from the ostioles or of any sticky liquid that would glue up the appendages of small insects. The smallest beetle larvæ are so delicate that 
they are at once immobilized or impeded in their movements when they happen to run or fall into a minute drop of water, and if the Ps. bromelix were at all hostile to the beetles or their larvæ in the manner described by šulc, their presence would not only be a nuisance but a serious menace to the colonies. The further fact that the coccids in a petiole are frequently decimated or even exterminated by several small predatory insects (vide infra p. 78) is also unfavorable to sulc's contention.

I am, of course, willing to admit that the ostioles may be glands or exudate organs which secrete substances that may be ingested by the beetles and their larvæ, but the closest observation of which I was capable showed that the oniy liquid visibly imbibed by the Coccidotrophus was the saccharine excrement, or honey-dew. If the secretion of the ostioles is a liquid, it must be emitted in droplets too minute to be visible under a Zeiss lens magnifying 20 diameter's, or it must be a volatile substance like that secreted by the peculiar tubular organs which occur on the eighth abdominal segment of many ant-attended Lycaenid caterpillars and have been described by de Niceville (1890). Thomann (1901) and others. ${ }^{1} \quad$ That the ostioles of Ps. bromelix may actually emit some substance attractive to the beetles and their larvæ is indicated by their often very prolonged stroking of the dorsal, lateral or anterior portion of a coccid. That they prefer to stroke its terminal abdominal segments may be due to the fact that that region bears both the anus and the posterior pair of ostioles.

The attraction of the mealy-bugs, whether due solely to their ability to excrete honey-dew or because they can also secrete some delicious exudate or fascinating aroma, is so great, that in populous colonies a single coccid may often become the center of a circle of actively competing beetles and larvæ of various sizes. This is not so apparent in colonies that have just been collected and placed in glass tubes, because the petiole still contains a certain amount of sap and the coccids are able to excrete normally, but after the colonies have been kept for several days or a

${ }^{1}$ Conf. also the paper of Newcomer (1912), who figures a section of one of these organs in Lycaena piasus (Pl. 2, Fig. 3). Although he believes that the tubular organs are not glandular, the structural details certainly seem to support Thomann's contention. 
week and the supply of water in the plant tissues has considerably diminished, the excretions of the coccids are less frequent and copious, so that the beetles and larvæ become more anıl more thirsty and therefore more desperate and exacting. Thus by the very simple device of keeping the colonies for some time in tubes, it is possible greatly to exaggerate the attentions of the beetles and their larvæ to the coccids and to witness certain peculiarities of behavior which are less obvious in recently collected colonies.

When a number of thirsty beetles and larvæ surround a large coccid, all stroking different parts of its dorsal surface and periphery, only the individual that happens to be stationed at its posterior end is able to secure any honey-dew. The beetles and larve all keep at work, however, till the antennæ of two of them happen to meet. Then the larger individual stops stroking for a moment and butts its competitor with the side of its head. If the group is formed by a single beetle and several larvæ, the beetle being the stronger, soon pushes any larva with which it may come in contact away, but the latter usually at once returns and resumes its stroking till contact with the beetle again occurs and the butting is repeated. When several larve of different sizes have preempted a coccid, the largest treats the others in the same manner. This behavior is so suggestive of that of a number of pigs eating out of the same trough that one can hardly doubt that something more than a mere reflex is involved in the butting. The larger beetle's or larva's indefatigable perseverance in butting is only equalled by the pertinacity with which the butted individual keeps returning and resuming its stroking movements. I can illustrate this best by transcribing a few observations from my note-book.

August 10, a beetle was seen standing over the posterior end of a large coccid and stroking it busily. At short intervals the coccid raised its anal segments and discharged a minute limpid globule of honey-dew, which was at once avidly seized and swallowed by the beetle. During 11 minutes the coccid raised its tail 25 times and the globule could be distinctly seen on most occasions, as the beetle paused suddenly in its manipulations and moved its labium and palpi each time a globule was imbibed. Sometimes the beetle would pause for a moment, 
before proceeding with its titillation and remain with its head flattened down, even when the coccid failed to move its anal segments. Once a large larva came up and endeavored to get some of the excretion but was promptly butted away, and once another beetle was treated in the same manner. After the 25 feedings the beetle moved away and another beetle came up and received from the same coccid four globules in less than two minutes.

August 12, I observed a beetle (No. 1), which was red and therefore immature, soliciting from a nearly full-grown coccid in a petiole collected a few days previously and already beginning to become dry. The beetle stroked the coccid for 15 minutes, during which time the latter produced only five droplets of honey-dew at intervals of two to five minutes. Then a mature, dark colored beetle (No. 2) came up and began to stroke the anterior end of the coccid, gradually moving back over it. Whenever the beetles met they butted each other with their heads or even locked mandibles for an instant and then returned to their former position and occupation. Beetle No. 1 worked for another 15 minutes without a reward. The coccid then rotated 180 deg. on its dorsoventral axis so that its anal end was now presented to beetle No. 2 , and inserted its beak into another part of the nutritive parenchyma. The beetle at once became more alert and accelerated the beat of its antennæ. During the succeeding eight minutes it received seven globules of honey-dew in quick succession, probably as a result of the coccid's change of pasture. Throughout this period beetle No. 1 kept titillating the coccid's side, pausing now and then for a few seconds, and after 40 minutes from the time I began the observation, moved away. Beetle No. 2 continued to stroke the coccid for some time, but I did not follow its behavior further.

In another colony at $8 \mathrm{P}$. M. on the same day I noticed a nearly mature beetle (No 3) vigorously stroking the hind end of a small coccid, while its sides were being stroked simultaneously by two just-hatched larvæ (A and B). From time to time other beetles and older larvæ came up and joined the party. Beetle No. 3 continually butted the newcomers away and they at last rather reluctantly departed, leaving the original trio in possession of the coccid. Every few seconds the beetle gave 
one of the larvæ a shove with its head, but the tiny creaturc instantly returned and went on with its stroking. At 8.14 the beetle gave $A$ such a vigorous knock that it stayed away from the coccid for some time. B, however, kept returning so pertinaceously that the beetle twice seized it in its mandibles for an instant and then dropped it. The larva was uninjured, however, and at once returned and went to work. Then the periodic butting continued till 8.35 when larva A returned and went to work with $B$ on the side of the coccid. One or the other was butted away by the beetle every few seconds till 9 P. M. During the entire hour the coccid remained stationary and unresponsive, never once raising its caudal segments nor emitting a droplet. All this time the beetle had remained in the same spot and had butted every beetle or larva with which its antennæ had come in contact. The beetles soon left after receiving a few knocks but the little larvæ $A$ and $B$, which seemed to be famished, persisted for a whole hour side by side, except for the 20 minutes during which $\mathrm{A}$ was absent. Larva $\mathrm{B}$ must have been struck by the beetle more than a hundred times. Finally the latter's patience seemed to be exhausted; it seized first A and then $\mathrm{B}$ in its mandibles, carried the latter three millimeters away from the coccid and hurled it to one side. Larva A returned, but $B$ had fallen out of the petiolar cavity onto the moist wall of the glass tube, adhered and was unable to leave the surface. The beetle now left the coccid and another very mature beetle (No. 4) took its place. It permitted larva A to stroke the posterior end of the coccid without molestation, but beetle No. 3 soon bustled up from the opposite direction, locked mandibles with beetle No. 4 and pushed it away. During the scrimmage the coccid suddenly raised its caudal end and discharged a droplet which was eagerly inbibed by the larva, at length rewarded for its incredible pertinacity and the innumerable knocks it had received. Then beetle 3 and larva $A$, now in undisturbed possession of the coccid but in the reversed position, the former being at the anterior, the latter at the caudal end of the coccid, continued their stroking, interrupted every few seconds by the butting of the beetle and the temporary withdrawal of the larva. This went on till 9.20. By that time my eyes which had been following the performance under the lens for an hour and twenty minutes were so fatigued that I had to desist from further 
observation, just after the beetle had tossed the larva to a distance of about four millimeters from the coccid by an unusually well-aimed blow.

Scenes of this description were so frequently enacted that they could be readily observed in almost any of the colonies after they had been kept for several days and the beetles, larvæ and coccids had all grown very thirsty. In such colonies the bodies of the coccids and larvæ become visibly attenuated and somewhat shrivelled as a result of the loss of water from the tissues of the Tachigalia petioles. All the insects now become restless. The beetles leave the petioles, wander about on the walls of the tubes and finally collect about the plugs of cotton in an endeavor to escape to the outside. The coccids, too, withdraw their beaks from the parenchyma in the floors of the foodgrooves and wander aimlessly about, vainly seeking more favorable pastures. But before this stage of demoralization is reached, both the beetles and the larvæ become cannibalistic and one may often see them, singly or in groups voraciously devouring partly dismembered larvæ or immature beetles. Within a few days all the larvæ and immature beetles are consumed, but the coccids, immune from attack, still wander about till they die of starvation.

I believe that Coccidotrophus is rarely or never cannibalistic under normal conditions. It is, as already stated, almost impossible to split a freshly gathered Tachigalia petiole containing one of the beetle colonies, without cutting some of the insects $i_{i 1}$ two, and such disabled individuals are soon devoured by their fellows, but both in such cases and in the cannibalism that supervenes in dried petioles, I believe that thirst or the need of water and not a veritable carnivorous instinct, such as seems to be manifested by some species of Cucujid beetles and their larvæ, must be regarded as the true explanation. I am confirmed in this view by Heins' recent investigations (1920) on meal-worms (Tencbiio molitor). He found that when the larva of this beetle are reared in dry meal as many as $24.2 \%$ of them may be devoured by their fellows, but that if wet slices of rusk or of vegetables are placed in the breeding jars the mortality from cannibalism is reduced to $7.5 \%$. In this connection Bodine's observations (1921) on grasshoppers are also of 
interest. He finds that during starvation, the loss of water in these insects is always greater than that in body weight or in the solids. "This shows that starvation in the grasshopper results in a rapid loss in water which has a decidedly quick and fatal effect."

I have been unable to ascertain the length of the larval period or the number of larval moults of Coccidotrophus. As no exuviæ were found in the petioles it would seem that they must be devoured either by the beetles or by the larvæ them. selves. The food of the larvæ, as we have seen, consists of the amber-colored nutritive parenchyma and of the sweet excreta of the coccids, the former evidently supplying the proteids, the latter the sugar and most of the water. So concentrated a diet should be very favorable for growth and probably the whole larval period at tropical temperatures occupies only two or three weeks. The fat-body, however, does not seem to become very voluminous till the last larval instar when the segments of the body become more convex and puffed out with the accumulations of adipocytes. Yet this condition, which immediately precedes pupation, does not tend greatly to inhibit the activities of the larva.

When a petiole containing a colony in what I have called the third stage is opened, one or more cocoons are invariably found in the cavity (Plate V). They are oblong-elliptical structures, 5-6 $\mathrm{mm}$. long and 2-3 mm. broad and seem to consist of the same chocolate brown substance as the frass-ridges. Their walls are of uneven thickness, with smooth inner and roughened outer surfaces, and are easily fractured. These cocoons do not lie loosely in the cavity but are attached to some flattened surface of the wall where the lumen of the petiole is rather broad, i.e., away from the pointed ends, and always have their long axes parallel with the long axis of the cavity. They are sometimes single but more frequently occur in pairs or in groups of three or four. When in pairs, the two cocoons lie abreast of each other, when in threes or fours, the third and fourth cocoon are often built on top of a basal pair. Such groups of cocoons are so voluminous that they obstruct the lumen of the petiole and leave only a narrow passage for the beetles to move between the more roomy spaces at either end of them. 
One naturally infers that either the larvæ must make the cocoons of frass or the beetles must envelop the pupæ with this material, but observation shows that both inferences are incorrect. The larva does, indeed, build the cocoon, but utilizes neither the frass nor the materials of old, abandoned cocoons in its construction. I have not seen the earliest stages in the process but it is evident that the larva selects a flat surface and begins to build a wall around an elliptical area, which thus becomes the floor of the cocoon. Little material is added to the wall at the end of the ellipse compared with the sides, where the material is built up as a pair of folds like those shown in Fig. $16 a$. I have seen several cocoons that had been abandoned in this or a somewhat more advanced stage, but on two occasions I was able to observe the completion of the structure from a stage like the one figured. Since in both cases the insects behaved in essentially the same manner I shall describe only one of them.

The larva was first seen working inside the cocoon in the stage of Fig. $6 a$, but it soon came out, wandered away to a distance of a few millimeters and, after careful search, bit off a minute particle of the living tissue of the petiolar wall, avoiding any frass-covered surface, returned, entered the cocoon at one end (left hand side of Fig. 6a), carefully masticated the particle with its maxillæ, while mixing it with saliva, applied it to the border of one of the folds, pressed it into place, crept out of the other end of the cocoon and went in search of another particle. Then it returned, entered the cocoon as before and repeated the building process. Excursions were made every few minutes and within a radius of 8 to 10 millimeters from the cocoon. The particles, which were selected with the greatest care and often after what seemed like some hesitation, were very minute and greenish when first bitten off but had become brown (by a process of oxydation?) by the time they had been incorporated in the walls of the cocoon. The particles were applied now to one fold of the wall, now to the other so that the edges became rather irregular (Fig. 6b), but as most of the particles were added to the middle of the folds, they began to approach each other. Still, their growth was very slow, owing to the minute size of the particles and the time consumed in their selection. The larva labored incessantly, making trip after trip and choos- 
ing every particle with the same diligence and avoiding the remains of empty cocoons in the immediate vicinity, although their materials, one would suppose, might have been easily appropriated and quickly built into the cocoon under construction. The two folds or side-walls slowly approached as the work progressed and eventually fused with each other, the larva always entering at the same end, applying the particle to one of the edges from the inside and leaving by the opening at the opposite end. Then it set itself to building the walls around this latter opening, which grew smaller and smaller (Fig. 6c), till the larva could no longer squeeze through it and was compelled when about to leave the cocoon to turn back on itself, bending its body in a loop with the two limbs in contact, and crawl out of the opening by which it had entered. This feat seemed to be accomplished with considerable effort but had to be performed after each particle had been built into the wall of the cocoon. Eventually the small opening was closed and the cocoon had only a single large elliptical orifice at one end (Fig. 6d). The larva now began to contract this orifice, but after a time, as it grew smaller, the insect on returning, no longer entered the cocoon and reversed its body in order to apply the particles to the edge of the orifice, but merely thrust its head and a few of its anterior segments into the cocoon and left the remainder of its body outside. At such times it used as a support or fulcrum a structure which I had not seen used at any previous stage of larval life, namely, the proleg which terminates the conical tenth abdominal segment. This structure is described by Dr. Böving (Zoologica III, No. 7) and clearly shown in his figures (Pl. VII, figs 1 and 2). When the size of the orifice had been reduced till the larva could only just squeeze through it, the insect entered the cocoon, reversed its position and continued building along the edges of the orifice with particles scraped from the inner surface of the structure. The orifice thus soon grew too small to permit the egress of the builder. (Fig. 6e). Then the imprisoned creature slowly closed the opening and the cocoon was completed (Fig. 6f).

A few days after the larva has thus immured itself, it sheds its cuticle and becomes a pupa which lies loosely in the cavity of the cocoon and has the appearance of Dr. Böving's Plate IX, figs. 
19-21. Owing to the minuteness of the particles used in building the cocoon, the care with which they are chosen and the many trips necessary to secure them, the time consumed in completing the structure is considerable. The earliest stage figured (Fig. 6a) was first seen at 8 P. M., July 25. By 6 A. M. the following morning the cocoon was in the stage shown in $b$. By $12.30 \mathrm{P}$. M. the small opening had been closed and the large opening was being contracted $(c)$. At $6: 30$ P. M. a small opening remained $(e)$, and the cocoon was completed an hour later $(f)$. As the first stage must have been the work of the greater part of a day, the structure was probably begun not later than $7 \mathrm{~A}$. M. on July 25th. At least 36 hours of continuous labor, requiring hundreds of trips back and forth between the cocoon and exposed patches of living parenchyma on the petiolar wall, were therefore consumed in completing the cocoon. The second larva observed in the act of building its cocoon was even slower, since the latter was first seen on the evening of July 26 in a stage corresponding to Fig. $6 a$ and was not entirely completed till after 10 A. M., July 29th. There was nothing to indicate that the first larva rested during the whole period of cocoon construction. While it was working in the manner described, it was occasionally annoyed by some young or half-grown larva entering the cocoon and using it as a hiding place while its architect was away gathering building materials. It was interesting to see the latter on its return oust the intruder, which scampered away with comical alacrity. When the cocoon is completed it is rather smooth externally but may later become rough through the beetles' plastering their frass over its surface. This certainly strengthens the walls of the structure.

I endeavored to keep the two pupre enclosed in the cocoons which I had seen built, in order to determine the length of the pupal period, but both died when the petioles dried out. The pupal period as inferred from other cases covers, at least, seven days. The callow emerging beetle under normal conditions gnaws a round or elliptical opening at one end of the cocoon and joins the other members of the colony. At first it is yellowish white and etiolated, with the legs, dorsal surface of head and prothorax and a transverse band on each segment of the venter pale red. It runs about very actively, nevertheless, and 
in the course of several days gradually takes on the deep chestnut brown color of the mature insect. But before this stage is reached, and while the male and female are still of a bright red or pale chestnut red color, they mate. On two of the three occasions on which I witnessed copulation both the male and the female were immature. The third couple, observed August 10 , consisted of an immature female and a mature male. It would seem, therefore, that mating occurs not only among immature beetles of the same generation soon after they leave the cocoons, but that old males of a preceding generation at least occasionally fecundate the recently emerged females.

The observation of August 10 is here transcribed from my note-book. The female was distinctly immature but uniformly red, i.e. no longer in the white, callow stage, and distinctly smaller and more slender than the male. The latter was certainly very nearly or quite mature. When first noticed the female was eating the parenchyma of the petiolar wall. The male mounted her back and remained for 18 minutes, clasping her sides with his legs and occasionally attempting to insert his aedoeagus. Now and then he rubbed her occiput from side to side with his mandibles and antennæ and sometimes shifted hir position very much to one side. The antennal movements were precisely like those employed in titillating the coccids. The female kept on feeding and pressed the tip of her abdomen against the wall of the petiole so that the male was unable to introduce his aedoeagus. He then dismounted and ran away but soon returned and attempted to mount and grasp the female again, but she was unwilling, slipt out from under him and escaped. He permitted her to go only a very short distance, however, before he again seized her just as she had stumbled on a coccid and had begun to stroke its posterior segments. While the male was strenuously endeavoring to copulate she continued to stroke the coccid and on this occasion kept the tip of her abdomen tightly pressed upward against the tips of her elytra. Then the male again dismounted and left her and she and another immature beetle turned their attention to a partly eaten larva which they proceeded to devour. In a moment the male, apparently in a high state of excitement, returned, mounted the female and this time succeeded in introducing his æodoeagus by 
forcing the tip of the female's abdomen downward and away from the tips of her elytra. During coitus, which lasted a little more than six minutes, the female continued to partake of the larva, but the male remained motionless.

\section{B. The Enemies of the Beetles and Coccids and the Decay of THE COLONIES.}

Attention has been called to the decay of the Coccidotrophus colonies when the flow of sap to the petioles is artificially cut off by severing the latter from the plant and both coccids and beetles are deprived of their nourishment. But even under the natural conditions of the jungle the colonies are doomed to decay, though from very different causes. As has been shown, Coccidotrophus lives only in the petioles of young Tachigalias growing in the shade and in these plants inhabits the petioles only till they are taken over by the obligate ants of the genera Pseudomyrma and Azteca. The beetles are not permitted, so to speak, to occupy their apartments after the rightful owners of the plant have become sufficiently numerous and aggressive to eject them. Sometimes this may occur even in rather young plants four to six feet in height. Still the period during which the beetles may be allowed to inhabit the young Tachigalias must cover several months. I infer this from the fact that during the more than two months of my stay at Kartabo I saw little change in the plants, which grew very slowly notwithstanding the almost daily, drenching rains, and their growth is probably almost nil during the dry season. Since the leaves are persistent, at least during the rainy months, there is ample time for the development of the beetle colonies, even if the growth of the larval broods and the coccids requires more than the three weeks above suggested. Throughout the latter part of July, August and the first half of September colonies were found in all stages, from those represented by a single pair of beetles to those comprising numerous beetles, larvæ, pupæ and herds of coccids. It would seem, therefore, that although the individual colony may live for only a few months, new colonies must be formed continually, at least during the rainy season, by emigration of pairs of young beetles from old colonies to other plants which have 
attained a sufficient size, i.e. have produced at least three or four fully developed leaves.

Still neither the beetles nor the coccids are permitted to live in perfect security till the obligate ants take possession of their quarters. Where competition among insects is so very keen as it is in the Neotropical jungle it is not surprising to find that several predators and parasites are continually gaining access to the petioles and decimating or even completely destroying their occupants. The greatest enemy of the beetles is the small thief-ant Solenopsis altinodis Forel (See p. 48 and Zoologica III, No. 4, p. 154), and the coccids have at least three formidable enemies. All of these insects enter the petiole through the openings made by the beetles and must therefore elude their watchfulness. We should expect the beetles to keep one of their number constantly on guard at the entrance, but they are neither sufficiently constant in this behavior nor sufficiently discriminating to keep out all intruders. When the petioles are taken into the laboratory the beetles are often seen to remain for hours with their heads in the entrances and their bodies at right angles to the longitudinal axis of the cavity, and even after the petioles have been split longitudinally and placed in vials the insects still exhibit this behavior, though it is now absurdly futile, since their domicile is wide open. But not infrequently even the single opening of a petiole may remain unguarded for long periods, and when the petiole has several openings some of them are apt to have no sentinels, so that predators and parasites small enough to pass the narrow orifices, have no great difficulty in gaining access to the colony. Moreover, a beetle that is guarding an opening may fight off certain intruders but back away and allow others to enter. On several occasions I held a beetle with its head to a guarded entrance. The sentinel at once grasped the stranger's head with its mandibles and pushed it away. But when I placed a worker Solenopsis altinodis in the same position, the beetle beat a hasty retreat and the ant climbed into the petiole. From these experiments we may infer that the beetles are more intent on keeping alien beetles of their own species than dangerous pests like the Solenopsis out of their nests. More probably some peculiar odor of the ant induces the beetle to withdraw. Thus while it seems to be probable that alien 
beetles are often kept out of the colony, the fact that the beetles of two or more colonies occupying different petioles, will, when the latter are split open and placed in the same tube, mingle without the slightest signs of hostility, would seem to show that even strange beetles may occasionaily enter an unguarded colony and become members of it in good standing. It has since occurred to me that female beetles, at least, might be permitted to pass the sentinels unchallenged. Unfortunately I failed to dissect and determine the sex of the beetles with which I experimented.

The laxity of the beetles in guarding the entrances is, indeed, amply proved by the presence in their nests of several species of insects, some of which are harmless or indifferent while others are injurious either to the beetles and their larvæ or to tne coccids. From analogy to the guests of ants, those of the former category may be called "synoeketes," or indifferently tolerated guests, the latter "synechthrans" (predators) and parasites. To the synoeketes belong a Collembolan, a mite and a small Phorid fly. The Collembolan is most frequently seen, especially in large petioles containing small colonies of beetles and therefore allowing ample space for its movements. It is a minute silver gray species, which Prof. Folsom has described and figured as Entomobrya whceleri (Zoologica III, No. 11), and occurs in droves of individuals of all stages, runuing hither and thither over the walls of the petiole, like certain species of the same genus (E. myrmecophila Reut. and dissimilis Mon.) and Cyphodeirus (C. albinos Nicol), which are often abundant in the nests of ants. Like the ants the Coccidotroplus pay no attention to these diminutive insects and are probably not even aware of their existence. The mites (Hypoaspis sp.) and Phorid flies (Aphiochata scalaris) were more rarely seen. They probably breed in the accumulations of refuse at the ends of the petiolar cavity and may therefore be regarded as scavengers, like the mites and Phorids which occur in many ant-nests.

Careful examination of the alimentary tract of the Coccidotrophus would probably show that the beetle harbors a number of entoparasites, at least certain bacteria, but I could not find the time to make such an examination when fresh material was available and my alcoholic specimens are worthless for the purpose. 


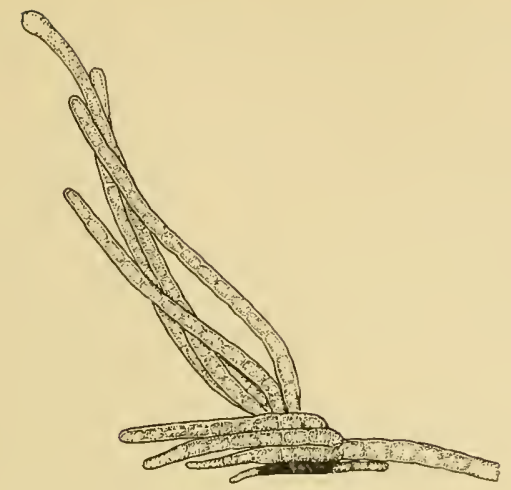

FIG. 12. HYPHOMYCETOUS PARASITE ON COCCI. DOTROPHUS SOCIALIS.

From a drawing by Prof. Roland Thaxter.

It seemed probable, nevertheless, that the beetle, living as it does in dark, moist cavities, might be infested with ectoparasitic fungi, especially of the group Laboulbeniales. I therefore requested Prof. R. Thaxter, the leading specialist in this group, to examine a large number of the beetles. After carefully scrutinizing their external surfaces he reports that he found no Laboulbeniales, but only a sterile Hyphomycete, growing on the elytron of one of the specimens. Referring to his work on the similar fungi of other insects he writes me as follows: "The fungus on the Coccidotrophus probably belongs to the group spoken of at the bottom of p. 237 in my first paper (1914), the most striking form of which (Aposporella elegans Thaxter), found on the wings of a small fly from the Kamerun, is figured on Plate III, Fig. 30 of the second paper (1920). These fungi seem to produce no spores and to reproduce by a kind of fragmentation; pieces breaking off with little or no differentiation, and starting to grow where they adhere. I have seen a considerable number of them on a variety of tropical insects, and ran across one of them a few days ago growing on a Laboulbenia from Kamerun. It has seemed hardly desirable to give names to such nondescript 
forms till it is quite certain that they have no differentiated type of reproduction." Prof. Thaxter kindly enclosed a drawing of the Coccidotrophus Hyphomycete which is here reproduced as Fig. 12.

The various organisms just described can, of course, have little or no effect on the health of the beetle colonies. Their decay and eventual extinction is due to ants destroying the beetles and their larvæ or to predators or parasites destroying the coccids on which they depend for an important part of their diet. Colonies in all stages may be invaded by the tiny Solenopsis altinodis, which I believe to be the most persistent and deadly enemy of the beetles. I have opened petioles containing both beetles and Solenopsis workers, but no beetle larvæ or only fragments of them, showing that the ants begin their depredations by slaughtering the offspring of the beetles. In such petioles the coccids remain uninjured, and the same is true of the pupæ immured in their cocoons. Many other petioles reveal conditions from which the last stages in the history of the colony may be inferred. In such petioles only dead beetles and a number of dead Solenopsis are found, indicating that the ants, after destroying all the larvæ, attack the beetles and that they, in the ensuing bitter conflict, often defend themselves with their powerful jaws to such good purpose that they succeed in killing many of the ants. But as more Solenopsis are probably continually entering the petioles as auxiliaries the beetles finally succumb and the colony is exterminated, with the exception of such pupæ as may be present in their protective cocoons. The beetles emerging from these may, conceivably, after the Solenopsis invasion is over, start a new colony in the same petiole or emigrate to other petioles. If no pupæ are present the petiole is sooner or later entered by a pair of young migrant beetles, which pack the dead bodies of the previous occupants, together with the ants they have slain, into the ends of the cavity and establish a new colony. In some of the colonies in the last stages of devastation above described, I failed to find any coccids. They may have been either eaten or carried away by the Solenopsis. Sometimes they remain undisturbed, however, and may, perhaps, be taken over by the beetles emerging from the cocoons or by any pair of young beetles entering the petiole and establishing a new colony. 
We can picture to ourselves the fierce battles which rage in the petioles between the beetles and the Solenopsis workers, probably mostly at night, for the Solenopsis is a nocturnal species, and the precarious life of the beetles in parts of the jungle where the ant is abundant. The beetles must live, in fact, like the ancient Greeks, always in danger of invasion from the warlike hords of barbarians. Yet even in quiet recesses of the jungle, where the Solenopsis may happen to be rare or absent, the attachment of the Coccidotrophus colonies to the Tachigalia is sure to be severed as the plant grows and the workers of the colonies started in one or more of the petioles by deälated queens of Azteca or Pseudomyrma have become sufficiently numerous to take possession of every petiolar cavity and patrol the whole surface of the plant. Perhaps some of the inquiline ants may occasionally kill or oust the beetles, but as these ants merely occupy a petiole here or there on the young trees, they cannot be regarded as very serious enemies. Many of them, too, are small, timid ants, which probably have their own battles to fight with the insidious Solenopsis and are destined to be supplanted, like the beetles, by the obligate Pseudomyrmas and Aztecas.

During the struggles between the beetles on the one hand and the Solenopsis, Pseudomyrmas, and Aztecas on the other, the poor coccids evidently play somewhat the same defenceless rôle as the cattle in a country overrun by contending armiesthey merely change masters and are either eaten, or carried off or permitted to remain and produce honey-dew for the victors. But before any such change of masters occurs they are often decimated or even exterminated by three enemies of their own, which may be briefly described seriatim.

In a few of the beetle colonies I have seen a number of larvæ of a very small Coccinellid beetle, described by Schwarz and Barber as Scymnus xantholeucus (Zoologica III, No. 6). These larvæ when full-grown resemble the larger coccids so closely in size, form and color and are covered with such a similar layer of snow-white wax, that I frequently overlooked them in my living colonies and detected their presence only in the preserved material after my return to the United States. They move slowly about among the beetles and their larvæ and devour the coccids. I am inclined to believe that by the time they are ready to pupate, 
they have also devoured all the beetle larvæ since I found two petioles each containing nothing but a pair of Scymnus pupæ, a few shrivelled remains of coccids and the kitchen-middens at the ends of the cavity. The pupæ were attached to the wall by their caudal ends and with their longitudinal axis parallel with that of the petiole. They were of a waxy yellow color, with their surface studded with short, blunt hairs. Several days later the imaginal beetles emerged. They measured $1.7 \mathrm{~mm}$. in length and $1.2 \mathrm{~mm}$. in width and were pale yellow, with the basal twothirds of the elytra, the meso- and metasternum and the median third of the first and second abdominal segments fuscous.

A much more abundant enemy of the the coccids is a peculiar predacious Itonidid (Cecidomyid) fly, which Dr. Felt has described as Diadiplosis pseudococci (Zoologica III, No. 8). The larvæ of this insect are orange red and are often found in clusters of as many as eight to a dozen around groups of coccids. The whole mass is covered by a tough, dense, white web, or tent, which is spun by the larvæ in such a way as to shut them and the coccids off from the cavity of the petiole and therefore from contact with the beetles or their larvæ. Thus secure from interference the Diadiplosis larvæ devour the coccids at their leisure, attacking them from the ventral side where their integument is thinest and free from wax. The coccids are eventually reduced to their dorsal integument. When mature the Diadiplosis larva pupates where it has been feeding, often in the midst of a group of young or full-grown larvæ, and without orienting itself with respect to the longitudinal axis of the petiole. Just before eclosion the pupa forces its body, head foremost, through the silken tent and projects into the cavity. The fly then emerges and probably either lays its eggs among any surviving coccids or emigrates from the petiole and enters other beetle colonies. 'The adult fly is a very delicate little midge measuring only 1.25 to $1.5 \mathrm{~mm}$. and of a reddish-brown color, with the abdomen red internaliy and the sclerites somewhat infuscated.

Considerable interest attaches to this insect, because, unlike the great majority of Itonidids and the species noticed above (p.50), it does not make plant galls but is predaceous. The genus Diadiplosis was originally established by Felt (1911a), for D. cocci Felt, a species reared in the island of St. Vincent from larvæ preying 
on the eggs of a coccid, Saissetia nigra Nietn., on stems of Sea Island cotton. In another paper published during the same year (1911b) he gives a list of 19 species of known zoophagous American Itonidids. The list includes species of Endaphis, Arthrocnodax and Mycodiplosis feeding on mites, an unidentified species of Cecidomyia feeding on the eggs of Cicada septemdecim, several species of Aphidoletes and Lestodiplosis preying on aphids and of Lestodiplosis, Dentifibula, Diadiplosis, Coccidomyia, Cecidomyia, Lobodiplosis, Mycodiplosis and Dichrodiplosis preying on various coccids. The Diadiplosis from British Guiana seems to be closely related to the type of its genus. According to Küster (1911), certain European Itonidid larvæ have been described by Rübsamen (1899) and Kieffer (1902) as preying on the larvæ of gall-makers of the same family.

Almost as abundant as the Diadiplosis in the beetle colonies is a Hymenopterous parasite of the Pseudococcus, namely Blepyrus tachigalix Brues (Zoologica III, No. 9), a small Encyrtid of the family Chalcididæ. The white larva of this insect lives in the coccid and grows with it, eventually becoming so voluminous that the coccid's body is very convex both dorsally and ventrally. The coccid grows increasingly sluggish and inert and its wax-glands cease to function so that its integument takes on a dull brownish color and the wax-pencils disappear from its periphery. The beetles and their larvæ are, of course, quite unaware of these profound changes in their parasitized cattle and still continue to stroke them, often for long periods, although there is no honeydew forthcoming as a reward for their efforts.

When full-grown the larval Blepyrus does not escape from the coccid but remains within it and forms an amber-colored, regularly elliptical cocoon about $2 \mathrm{~mm}$. long and therefore very nearly as large as the coccid, which is now reduced to a mere skin enveloping the huge parasite. The cocoon seems to consist of a hard, glassy substance, possibly a modified silk, and is covered except on its ventral side with small circular spots which represent thinner, depressed areoles in its wall. Where these areoles are lacking on the ventral side the wall is homogeneous and distinctly thinner than elsewhere, but has a number of small pointed projections which seem to pierce the ventral integument of the coccid and to attach the cocoon rather firmly to the wall of 
the petiole. Since the parasitized coceid remains in the foodgroove with its body in the usual position the cocoon necessarily has the same position and orientation, i.e. with its long axis parallel with the long axis of the petiole. The cocoon gradually grows darker, passing from amber-yellow to dark brown and by the time it has reached this stage, the dead tissues of the coccid enveloping it, except those on the ventral side, between the cocoon and the wall of the petiole, disappear, leaving the lateral and dorsal surfaces of the cocoon fully exposed. I am inclined to believe that the dead tissues of the coccid are eaten away by the beetles or their larvæ, but as they are very soft and disintegrate easily, they may perhaps be rubbed off merely by the attrition of the insects as they move back and forth in the petiole. Two of the denuded cocoons in the stage and with the orientation just described are shown in Fig. 11.

When the completed Blepyrus cocoon is cleared in carboixylol, mounted in balsam and examined as a transparent object, the larva is found to have pupated within it, after extruding a number of large meconial pellets, the undigested remains of all the food it swallowed while it was living on the tissues of its host. In most cases, at least, the head of the pupa is at the caudal end of the coccid. The imago, when mature, cuts a large round hole in the end of the cocoon (see upper part of Fig. 11) and emerges as a short, thickset, broad-headed fly, only $1.5 \mathrm{~mm}$. long, with a metallic green face, a black, more or less bronzed body, black and yellow antennæ and legs and basally infuscated wings. It is very active, and like other small Encyrtids skips about by using the long saltatory spurs on its middle tibiæ. After mating the female undoubtedly oviposits in the young coccids either in the same or in some other beetle-inhabited petiole.

This parasite seems not to be nearly so serious a menace to the Coccidotrophus colonies as the Scymnus and Diadiplosis, since the infested coccids are probably able to supply the beetles and their larvæ with honey-dew till both host and parasite are nearly mature. Hence one often finds several infested coccids and Blepyrus cocoons in petioles inhabited by flourishing beetle colonies. In one such colony I counted more than fifty cocoons and a dozen large coccids swollen with parasites that were still in the larval stage. 
I have failed to find more than one of the three species of coccid enemies in a single petiole. Their combined action, if they actually ever occur together, would, of course, not only greatly hasten the extermination of the coccids, but would seriously interfere with their own development. It may be noted incidentally that none of these enemies occurs in the petioles of the large Tachigalias inhabited by the obligate Pseudomyrmas and Aztecas. In such plants the coccids are free from all predators and parasites and are not only more numerous but attain a larger size than in the petioles of the small shade trees tenanted by the Coccidotrophus. The ants are undoubtedly much more efficient than the beetles in keeping small miscellaneous guests and synoeketes out of their nests. This is particularly true of the Pseudomyrmas. Although I have collected the entire colonies of many of these ants on several different trips to the American tropics, the only synoekete I have ever seen associated with them was a Microdon larva described many years ago (1901) from the nest of Pseudomyrma mexicana Roger. Even coccids are kept and attended by only a few species of Pseudomyrma.

Before concluding my account of Coccidotrophus I may introduce a few statistical data, which are probably valid only for the particular time and locality of my observations. While at the Tropical Laboratory I noted roughly the condition of the contents of each of the Tachigalia petioles I opened on a particular day. On some days only a few petioles were opened and the results are not worth transcribing. The following collection, however, gives a more interesting picture owing to the number of petioles examined:

August 9. Collected 253 petioles from young Tachigalias $11 / 2$ to $7 \mathrm{ft}$. high growing along the Cuyuni Trail. Of these 37 or about $14 \%$ were either too young to have inhabitants or contained solitary Pseudomyrma queens founding colonies or smali colonies of inquiline ants; 203 or about $86 \%$ either contained or had contained beetle colonies. Of the latter number, 50 contained incipient colonies, i.e., a single pair of beetles or more rarely single beetles which had just entered the petioles and were busy "cleaning house." In one petiole one of the beetles of a pair was guarding the entrance while the other was shovelling frass and the remains of previous occupants with the top of its head into 
the pointed ends of the cavity. Sixty-four of the beetle colonies had larvæ and were in what I have called the second and third stages. In nearly every case coccids were seen. Eighty-nine of the colonies were either moribund or extinct. Solenopsis altinodis workers either living or dead, were present, sometimes in considerable numbers, in 35 of these petioles, and 10 of them still contained large coccids that had been shut off by webs and were being devoured or had been already devoured by Diadiplosis larvæ. In one petiole two of the flies had emerged. In 6 of these petioles the Solenopsis workers had destroyed the beetles and their larvæ and were still running about. When I tore away the webs covering the Diadiplosis larvæ the ants at once seized and killed them. The webs serve, therefore, not only to protect the Itonidids from the beetles and their larvæ, but also from the Solenopsis.

\section{Eunausibius WheEleri SCHWARZ AND BARBER.}

This beetle, though superficially very similar to Coccidotrophus socialis, can be easily distinguished in all its postembryonic stages. The adult beetle (Plate III, fig. 1, Plate VI, figs. 6 to 10 ) is distinctly smaller, measuring only $3-3.5 \mathrm{~mm}$., permanently of a red color like the immature Cocidotrophus and therefore never deepening into the dark chestnut color of the latter. The antennal clubs are larger and broader and much more distinctly marked off from the more proximal joints, the eyes are much larger, the anterior border of the front is much less deeply emarginate, the femora are less incrassated and the posterior pair has a small tooth on the flexor side. The surface of the body is smoother, the punctation being less pronounced. The larva is more slender, with the head and dorsal surface distinctly gray, owing to a deposition of fine pigment granules in the integument. The pupa can be at once recognized by the presence of four large, equidistant tubercles on each of the parallel lateral borders of the pronotum (Fig. 8a, Plate IX, fig. 23). For many of the less obvious differences between the various instars of the two beetles the reader may be referred to the excellent descriptions and figures of Schwarz and Barber (Zoologica III, No. 6) and Böving (Zoologica III, No. 7). 
The prominent tubercles on the sides of the pupal pronotum of Eunausibius merit somewhat fuller consideration, because they present a striking instance of the retention in an earlier ontogenetic stage of a character which may be completely lost in the adult. An examination of the common saw-toothed grainbeetle, Oryzaphilus (formerly Silvanus) surinamensis L., represented in Fig. 7, and other species of the same genus, shows that the adult beetle has six acute teeth on each of the lateral borders of the pronotum, corresponding to and arising within as many large, blunt tubercles of the pupa. These structures were long ago noticed by Coquerel (1849) and Perris (1852) and by the former erroneously supposed to be portions of some tracheal system peculiar to the pupa. In Nausibius ( $N$. clavicomis) the pronotum of the beetle bears six obtuse teeth on each side. In other Silvanid genera, such as Silvanus and Cathartus as well as in Eunausibius and Coccidotrophus these teeth are either altogether absent in the imago, or reduced to the first pair, which form the anterior corners of the thorax. Eunausibius has well-developed teeth in this position but in Coccidotrophus the anterior corners of the pronotum are merely rectangular. It is therefore interesting to find that the pupa of Eunausibius has four well-developed pairs and a fifth vestigial pair of tubercles, that these tubercles decrease in size anteroposteriorly, and that only the first pair gives rise to teeth that persist in the adult. In Coccidotrophus the reduction of the pupal tubercles is carried much further since there are only small vestiges of the three anterior parts of Eunausibius, none of which gives rise to teeth in the imago. Moreover, the second and third pairs of pupal tubercles may be represented by only a single tubercle on one side of the pronotum, as Böving observed (Zoologica III, No. 7). The tubercles are, in fact, so evanescent that they have become very variable, like vestigial organs in general. This is seen in Fig. 8-b to $f$, representing the prothoraces of five Coccidotrophus pupæ selected from a series of fifty specimens. We may safely conclude, therefore, first, that Eunausibius and Coccidotrophus are derived from ancestors which had a 12-toothed pronotum like the species of Oryzaephilus; second that this condition disappeared first in the imago and still tends to linger on in the pupa, and third, that the tubercles have a tendency to disappear in sequence in a posteroanter- 
ior direction. There can be little doubt that the dentation of the sides of the thorax is a very ancient character not only in the Silvanids but also in the Cucujids (as restricted by Böving), since vestiges of the teeth can also be clearly seen in the imagines of certain genera of the latter family (Cucujus, Brontes).

I have already alluded to the fact that Eunausibius colonies are much rarer at Kartabo than those of Coccidotrophus though both species may occur in the same localities and even in different petioles of the same young Tachigalia. And not only are all the instars of Eunausibius smaller than those of Coccidotrophus but the colonies are also much less populous. The largest I have seen consisted of less than a dozen beetles and not more than two dozen larvæ. The habits, so far as I have been able to observe them, are much like those of Coccidotrophus. The Eunausibius also feed on the nutritive parenchyma in the walls of the petiole but they do not dig long grooves in the tissue but only narrow elongate pits, nor do they build up their frass in parallel or vermiculate ridges but plaster it in a thin layer over the walls of the petiole, so that the latter are smooth and even. The elongate entrance to the petiole seems not to be provided with a wall of frass. In one petiole I found that the pair of parental beetles had entered through a large hole about $2.5 \mathrm{~mm}$. in diameter which had evidently been made by some larger insect. The beetles had plugged the opening with frass, leaving a small elliptical opening in the center just large enough to fit the head of the beetle when acting as a sentinel. Coccids are found in the elongated pits in the nutritive tissue but are few in number and of small size, though the Eunausibius solicit and drink their saccharine excretions in the same manner as Coccidotrophus. The cocoons of Eunausibius, apart from their smaller size and somewhat more delicate walls, are very much like those of Coccidotrophus and are, in all probability, constructed in the same manner.

I have seen so few colonies of Eunausibius that I can give no account of its enemies nor of those of its coccids. In all probability it is even less able than the more vigorous and more prolific Coccidotrophus to withstand the insidious attacks of Solenopsis altinodis. The whole appearance of the beetle and its colon- 
ies is that of a feeble, anæmic and harried species on the verge of extinction.

\section{General Considerations}

The behavior of the social Silvanids described in the preceding pages and the conditions under which they live are sufficiently startling to stimulate reflection and a comparison with other species of the same and allied families. Such comparison, as an ethological method, has so often thrown light on what appeared at first sight to be unique and incomprehensible instincts and their settings that we may hope by resorting to it to trace the peculiar conditions in Coccidotrophus and Eunausibius to simpler and more general phenomena. Since both the setting, or environment and the responses, or behavior of the beetles are rather complicated it will be best to consider them separately and to begin with the setting, i.e. with the Tachigalia biocoenose.

The general ethological concept of the 'biocoenose' was, of course, more or less clearly recognized by many of the early zoologists. Although the term seems to have been first used by Möbius (1877), even Rèaumur had an inkling of the value of studying insects in association with their host plants. He says: "I would that the observers who busy themselves with the history of insects gave catalogues of those that feed on every plant." In the middle of the last century Perris (1852-1862) devoted many years to the study of the insects associated with the maritime pine and the chestnut in France, and Kaltenbach (1874) attempted to list all the phytophagous insects of Germany according to their host plants. In the United States Packard's volume (1881) on the forest and shade-tree insects and Mrs. Dimmock's paper (1885) on the insects of the birch represent more modest studies of the same kind. Perhaps none of our entomologists has been more thoroughly convinced of the advantages of studying insects and other animals as components of biocoenotic complexes than Forbes. Forty years ago he expressed his general convictions on this subject in his paper on the food of fishes and insects (1880) and he has returned to the subject in a recent address (1915). His fine papers on the strawberry and maize plants and their associated organisms (1884, 1894-1905) also clearly illustrate the great value of biocoenotic investigations. 
Picard (1919) has recently published an interesting paper on the insects of the fig in Southern France.

As a mere record of the insects associated with a tropical plant my study of the Tachigalia biocoenose is necessarily fragmentary, owing to the few weeks I could devote to it, but it acquires considerable interest from the fact that the Tachigalia is a myrmecophyte, or one of those plants which are supposed to be peculiarly adapted structurally to association with battalions of protecting ants. The only organs which can be cited, however, as such an adaptation are the fusiform enlargements of the petioles, which undoubtedly furnish excellent lodgings for all the various ants, both inquiline and obligate. The plant is utilized also as a source of food by the obligate species through the instrumentality of the coccids, which are kept in the petioles and draw their food by preference from the strands of nutritive parenchyma. The beetles also use the petioles as lodgings and not only utilize the species of coccid as a copious source of sugar and water but also feed directly on the tissues of the plant. The plant is therefore more completely exploited by the beetles than by the ants and might be said to be more perfectly adapted to the former than to the latter. But the question as to whether the peculiar structure of the petiole is really an adaptation to either of these groups of insects is one which I shall leave to the botanist. Prof. Bailey will no doubt deal with it in connection with the same problem in the other South American myrmecophytes which he has investigated. That both the ants and the beetles have adapted themselves to the plant cannot be doubted and this adaptation, as I have shown, is exhibited in three degrees, the inquiline ants merely using the petiolar enlargements as lodgings, the obligate ants as lodgings and through their herds of coccids as indirect sources of food, and the beetles as lodgings and as both direct. and indirect sources of nutriment.

Of course, a particular biocoenose is not an isolated, perfectly self-contained association of organisms but shares some of its components with other biocoenoses. Thus the Tachigalia is part of a large association, or biocoenose of jungle trees growing under certain conditions of soil, humidity, light, temperature, etc. The Atta ccphalotes, which occasionally defoliates the young tree is the center of an elaborate biocoenose of its own, 
comprising all the trees it habitually defoliates, its fungus gardens, its myrmecophiles of the Blattid genus Atiaphila, the toads, lizards and ant-eaters which feed on the foraging workers, the Amphisbaenians which live in the penetralia of the huge nests, etc. The two ants, Camponotus femoratus and Crematogaster parabiotica, which attend Membracids on the young shoots of the Tachigalia, are really characteristic members of the very peculiar "ant-garden" biocoenose, which I have described in another paper (1921), and the Dolichoilerus attelaboides belongs to still another biocoenose of which many Melastomaceous plants and their Membracid parasites are important components.

A particular biocoenose must also, of course, have a phylogenetic history, i.e. we must conceive it to have been gradually built up, integrated and organized in time from components which detached themselves from other biocoenoses and attached themselves as satellites to an organism which furnished more congenial conditions of life. Owing to the basic nutritive interdependance of animals and plants, a particularly favorable plant usually constitutes the primary focus of a biocoenose. The various parasites, scavengers and synoeketes, which live with the insects that immediately depend on this plant merely use the former as so many secondary or tertiary foci. Thus in the Tachigalia biocoenose the primary focus is the young plant and the center of the focus the leaf-petiole, the secondary focus is represented by the coccids and the tertiary foci by the ants and beetles to the extent that they attract predators, parasites and scavengers.

It is permissible, perhaps, to reconstruct the phylogenetic sequences of the various organisms that have become associated to form the Tachigalia biocoenose. Not improbably the tree, like many other trees of the Neotropical jungle, was originally peopled throughout its life by a certain number of miscellaneous, inquiline ants. Among these were several species of Pseudomyrma and Azteca, both large genera comprising numerous forms which still habitually inhabit any available hollow twigs or petioles of the most diverse trees and shrubs. Later the number of these ants was reduced, through the advent of the coccids and their definitive association with the Tachigalia, to a very few species, the putative ancestors of the present Ps. damnosa and 
maligna and $A$. foveiceps, because the coccids enabled them to acquire very intimate trophic relations to the plant. The coccids present an unsolved problem in this connection. It would seem that the Tachigalia must be their true host-plant, and that the various other plants on which they are known to live, are subsequent, or secondary hosts, possibly acquired when the natives of British Guiana and of the surrounding countries took to making clearings in the jungle and growing in them various introduced plants such as pine-apples, Hibiscus, etc. The truth of this statement can, of course, be established only by further investigation of Pseudococcus bromelix throughout its range. When the obligatory ants had thus acquired their definitive attachment to the tree, the miscellaneous inquilines necessarily became restricted to its youngest stages since they were no longer able to compete with the obligates for the possession of nesting sites on the adult plant. The Silvanid beetles were probably relatively late intruders which found that they could inhabit the young tree for a considerable period before the queens of the obligate ants had succeeded in maturing their broods of belligerent workers. At first the beetles merely used the petiolar cavities as lodgings and fed on the nutritive parenchyma in their walls, but later they discovered the coccids and learned how to obtain their honey dew and came to depend more and more on this saccharine nutriment. The various parasites, scavengers, etc., which infest the beetle colonies and their droves of coccids obviously represent still more recent accessions to the biocoenose. The other insects, such as Atta cephalotes, the Membracids and their attendant ants, the caterpillars and gall-flies of the leaves, etc., may belong to the ancient miscellaneous fauna which originally attacked or frequented the Tachigalia in all its stages, when it was quite as "unprotected" as the great majority of jungle plants.

Turning now to a consideration of the beetles themselves, it would seem to be desirable to review their activities in the light of what is known concerning the other members of the natural family to which they belong. Here, however, we encounter difficulties, for the family Cucujidæ (sensu lato) has been more neglected by taxonomists and students of insect behavior alike than any other family of equal size in the order Coleoptera. 
As understood by Coleopterists the family Cucujidæ belongs to the huge and very inadequately analyzed Clavicorn complex of families, but its characters are so striking that they have arrested the attention of some of the specialists. Thus Leconte and Horn (1883) long ago remarked: "This family is evidently an antique and synthetic type, which exhibits alliances with both Heteromera and Rhynchophora more than any other Clavicorn family." And Handlirsch (1908) says: "The family Cucujidæ, which Ganglbaur places in the midst of typically Clavicorn forms, exhibits many primitive characters and at the same time high specialization. I do not believe that their antennæ can be derived from those of the Clavicorn type, although the Cucujids agree with this group in the number of their Malpighian tubules (six). Perhaps the Cucujids branched off very near the base from the Cantharid stem, but possibly, and I regard this as more probable, they form an independent series." In his phyletic tree (opposite p. 1278), Handlirsch therefore depicts the family as arising from the Protopolyphaga as far back as the beginning of the Coenozoic. Several species of Silvanus and one of Passandra are, in fact, known from the Baltic Amber (Lower Oligocene Tertiary), and Wickham (1920) cites Laemophloeus vestitus Scudder from the Green River Eocene and three species of Lithocoryne and a Pediacus from the Miocene of Florissant. That the family must be an old one is indicated also by the fact that New Zealand possesses some 20 indigenous species of Cucujidæ, distributed over 12 genera, mostly peculiar to the islands, which are said to have been separated from Australia during the Jurassic.

Kolbe (1910) is also of the opinion that the Cucujids are a primitive group. He says: "The very lowly organized Cucujids are not only in part characterized by a prothorax of very primitive structure (as in the Adephaga) but primitively inserted (inframarginal) and primitively constructed (filiform or moniliform) antenne." Leng (1920) places the Cucujids in the lower portion of the series of Clavicorn families, near the Rhizophagidæ and Erotylidæ. In a brief study of the larvæ of Cucujids, de Peyerimhoff (1902-'03) calls attention to their great diversity and their resemblance on the one hand to the larvæ of Cryptophagus among the Clavicorns and on the other to Pyro- 
chroa among the Heteromera. Hamilton (1886) long ago noticed the resemblance of the larval Cucujus clavipes to the Pyrochroid Dendroides canadensis larva. As shown in his very valuable paper on the larvæ of Coccidotrophus and other genera (Zoologica III, No. 7) Böving divides the Cucujidæ anctorum into four families, the Silvanidæ, Cucujidæ (sens. str.), Læmophlœidæ and Scalariidæ. The last of these he relegates to the group Cleroidea, and states that they are closely connected with the family Bothioderidæ of Craighead (1920).

Apart from several species of considerable economic importance, the little that is known concerning the habits of these four families of beetles is scattered through the literature. Such data as I have been able to glean in regard to the European, North American and cosmopolitan species have been brought together in condensed form in Zoologica III, No. 5. From these data it will be seen that the Cucujids, taken as a whole, exhibit certain tendencies which are not without significance in connection with the peculiar behavior of Coccidotrophus and Eunausibius. If we exclude the Scalariidæ, which Fiske (1905) has shown to be parasitic in their larval stages-resembling in this respect the Bothrioderidæ-we notice that the various genera and many of the species of the remaining families show an extraordinary diversity, one might say versatility of behavior. They occur in a great variety of habitats such as stored human foods of vegetable origin, under bark, in decaying wood, in the burrows of bark-beetles, under dead leaves and rubbish, and feed on all sorts of substances mainly of a vegetable and especially of a concentrated or highly nutritious character. Many of the species are scavengers, others are undoubtedly predaceous and prey on the larvæ of other insects. The adult beetles seem to be rather long-lived and usually, if not always, live gregariously with their larvæ, all the active stages feeding on the same substances. The developmental period is certainly very brief in some species, as e.g. in Cathartus advena, the whole life-cycle of which, from the egg to the imago may require only three weeks and in the saw-toothed grain beetle (Oryzæphilus surinamensis) less than a month. As a rule both the beetles and the larvæ of the vegetarian and detritivorous species are very tolerant of the presence of other insects and actually seem to seek their compan- 
ionship, especially when the food supply is abundant. Thus $O$. surinamensis is often found living with the rice weevil (Calandra oryzæ), Cathartus advena with the Indian meal moth (Plodia interpunctella) and $O$. mercator with a Tenebrionid grain-beetle, Palorus subdepressus. Many of the species of Lxmophloeus constantly live in the burrows of Scolytid beetles and feed on their dejecta. Owing to these peculiarities and especially to their very diverse and plastic feeding habits many of the Silvanids and Læmophloeids have become cosmopolitan household pests capable of doing considerable damage to many of the staple stored foods of our own species.

If with this general complex of behavioristic tendencies exhibited by the European and North American Cucujids (sens. lat.) we compare the activities of Coccidotrophus and Eunausibius, we find that the latter while retaining many of the ancient and primitive family traits nevertheless exhibit several of them in a peculiar and highly specialized form. Thus the merely gregarious habits of the adults and larvæ of the northern and cosmopolitan Cucujids have become more definitely social in the Tachigalia beetles, and their toleration of alien insects has increased; the feeding of the ancient Cucujids on various vegetable substances has become specialized to the point of concentration on a particular tissue of a particular plant and both adult beetles and larvæ have become coccidophilous. The construction of the cocoon, too, exhibits peculiarities not found in any other Cucujids. Owing to the unusual interest of these various specializations they may be discussed at greater length under separate captions.

\section{Social Life Among the Coleoptera}

If we regard as truly social only those insects in which the parent or parents live with their offspring, protect them and either feed them directly or prepare materials for their sustenance, there seem to be only three groups of beetles that meet these requirements, namely, the Platypodidæ, the Scolytidæ (Ipidæ) and the Passalidæ. The Platypodidæ and that portion of the family Scolytidæ, comprising, according to Hagedorn (1910) the tribes Corythalinæ, Xyleborinæ and Spongiocerinæ, with some 400 described species, mostly tropical, are commonly known as 
ambrosia beetles, because like the Attiine ants of the Neotropical Region and many Old World termites they cultivate fungi as food for themselves and their larvæ. The remarkable social organization and the food-fungi of these beetles have been studied by Eichhoff (1881), Hubbard (1897a, 1897b), Hopkins (1898), Neger (1908a, 1908b, 1909, 1911), Schneider-Orelli (1911a, 1911b, 1912, 1913) and others, Hubbard's account of the habits of Platypus compositus of our Southern States is so interesting that I quote it at length :

"These social instincts reach their highest development, apparently in the genus Platypus. The species of this genus are readily known by their very long cylindrical bodies, their prominent head, flattened in front, the flattened and spur-tipped joint of the front legs, and in the males the spine-like projections of the wing cases behind. They are powerful excavators, generally selecting the trunks of large trees and driving their galleries deep into the heartwood. The female is frequently accompanied by several males, and as they are savage fighters fierce sexual contests take place, as a result of which the galleries are often strewn with the fragments of the vanquished. The projecting spines at the end of the wing cases are very effective weapons in these fights. With their aid a beetle attacked in the rear can make a good defence and frequently by a lucky stroke is able to dislocate the outstretched neck of his enemy. The females produce from one hundred to two hundred elongate-oval pearly white eggs, which they deposit in clusters of ten or twelve in the galleries. The young require five or six weeks for their development. They wander freely about in the passages and feed in company upon the ambrosia which grows here and there upon the walls. The chitinous ridges upon the thoracic segments, together with the row of tubercles upon the other segments, enable the larva to move as rapidly through the galleries as if it were possessed of well-formed legs. The mouthparts of the larva are also provided with strong cutting mandibles, but the inner jaws are not adapted to masticating hard food, such as particles of wood. The older larvæ assist in excavating the galleries, but they do not eat or swallow the wood. The larvæ of all ages are surprisingly alert, active and intelligent. They exhibit curiosity equally with the adults, and show evident regard for the eggs 
and very tender young, which are scattered at random through the passages, and might easily be destroyed by them in their movements. If thrown into a panic, the young larvæ scurry away with an undulating movement of their bodies, but the older larvæ will frequently stop at the nearest intersecting passageway to let the small fry pass, and show fight to cover their retreat. When full grown the larva excavates a cell, or chamber, into which it retires to undergo its transformations. The pupa cells are cut parallel with the grain of the wood and generally occur in groups of eight to twelve along some of the deeper passages. The older portions of the galleries are blackened by the longcontinued formation of the food fungus. In the ambrosia of Platypus compositus the terminal cells are hemispherical, and are borne in clusters upon branching stems."

The habits of several genera of ambrosia beetles of the family Scolytidæ were investigated by Hubbard, and one of our species, Xyleborus xylographus, which has an extensive circumpolar distribution and is common in the wood of fruit-trees, has also been studied by Eichhoff (1881) and Hopkins (1898). I quote the latter's account of this insect which may serve as a paradigm of the whole group:

"The fertilized females pass the winter in their brood chambers and emerge in the spring (April and May, near Morgantown, W. Va.). They are then attracted to sickly, dying or felled trees, in the living or moist dead wood of which they prefer to excavate their brood galleries. A crevice or opening in the bark, such as may be made by other insects, or, as I have observed, those made by the yellow-bellied woodpecker, but more commonly the edge of a wound, in a dead place on a living tree, is selected as a favorite point of attack. Here a female will commence the excavation of a mine, and after she has penetrated the wood a short distance, another female (as I have observed) will come to her assistance, one working at the excavation, while the other guards the entrance and assists in expelling the borings. The primary or main gallery is usually extended into the heartwood before eggs are deposited. When the primary gallery is completed (according to Hubbard) a bed is provided on the sides of the gallery for the propagation of the special species or variety of ambrosia fungus which is to furnish food for the 
future broods. The first set of eggs are few in number (five to ten) and are placed without any protection on the sides near the end of the main gallery, or in cavities or short branching galleries, one-half to one inch from the end, where upon hatching, the young larvæ find a supply of ambrosial food. After the first set of larvæ have attained considerable size, another set of eggs are deposited, and so on at intervals until a large family is reared, in which eggs, larvæ of all stages of development, pupæ, and young and old adults are found crowded promiscuously in leaf-like brood-chambers which are continually broadened or extended by the adults and possibly by the larvæ, to make room for the increase. It appears that the brood-chambers are broadened and extended by the adults, and that the borings, mixed with the fungus, are softened and furnish additional food for the larva and young beetles." At this point in his account Hopkins introduces the following note: "In a brood-chamber bejore me just cut from a nearby apple tree, I find a pupa minus an abdomen. No predaceous enemies can be found, but two or three half-grown larvæ are in such a position as to make the circumstantial evidence quite plain that they are to blame for the multilation. The remaining portion of the pupa is in a normal condition, which would indicate that the attack had been recent and when the victim was alive. This would also indicate that the helpless pupæ may furnish food for the larva in case of a scarcity of ambrosia, or that they may be thus disposed of to prevent an overcrowded brood-chamber."

The account of Xyleborus continues: "Mr. Hubbard records the discovery of a death chamber, or a kind of catacomb, in which the dead mother beetles and other dead friends or foes of a large colony are consigned by the survivors. In some fresh specimens of galleries before me I find the same thing, but it appears that in addition to a resting place for the dead, it is also utilized for the disposal of all objectional and refuse matter, which owing to the crowded condition of the chamber, cannot be conveniently expelled from the entrance. One of the males found in this set of chambers was excavating a burrow in the mass of material in the death or garbage chamber. Whether he was excavating his own tomb, or simply providing bachelor quarters, I cannot say. The proportion of males in this, as in 
all other species of the genus Xyleborus, is remarkably small. There are usually not more than three males in the largest colonies, or groups of brood-chambers. It would appear from observations made by Swiner and Eichhoff in Germany, and the numerous colonies I have examined in this country that there is, on an average, about one male to twenty females. The males have no wings, therefore probably do not leave the brood-chambers, but remain with the over-wintering colony until all have emerged in the spring. They are then left to be smothered in overabundant ambrosial food, or to the tender mercies of predatory insect enemies which had previously been prevented from entering the brood-chambers by one or more female sentinels at the entrance. A few females may emerge from time to time during the summer to start new colonies, but from the excessively crowded condition of the brood-chambers during the fall and winter months, it would appear that the older adults of the broods excavate branching chambers in which new broods are developed, and that in these old and new chambers they pass the winter."

The third group of social beetles comprise the large Lamellicorns of the family Passalidæ, abundant in the tropics of both hemispheres but represented in the United States by only a single species, Passalus cormutus Fabr., which ranges as far north as Massachusetts and Illinois. None of our Coleopterists seem to have taken the trouble to study the habits of this common and conspicuous insect, so that it was left to Ohaus (1899-1900, 1909) to discover the social behavior in certain Brazilian species. He found that they live in rotten logs in colonies, each consisting of an adult male and female with their larvæ. The beetles excavate spacious galleries, comminuting the wood and probably treating the particles with some digestive enzyme, so that they can be eaten by the larvæ, which slowly follow along the galleries just behind their tunneling parents. Owing to the structure of their mouthparts the larvæ are quite unable to break down the wood, and when removed from their parents soon die. The beetles not only guard their greenish eggs and diligently provide food for their larvæ, but also protect the pupæ and feed the imaginal young till their chitinous integument is completely hardened. In a former paper (Wheeler and Bailey, 
1920) I have published an account of the stridulatory organs of the larval and adult Passalus and have given reasons for believing that all the members of colony are kept together by the shrill sounds they are able to emit.

During the summer of 1920 while in Trinidad and British Guiana my son Ralph and I made a few observations on severai of the species of Passalus which are very common in rotten logs throughout the jungle. Just under the bark the beetles make large, flat cavities, which are later very often occupied by the fungus-growing ants of the genera Apterostigma, Myrmicocrypta and Cyphomyrmex, and evidently furnish just the right places for their more or less globular gardens. In each of the Passalus colonies examined during July and August there were only two adult beetles, usually accompanied by a troop of larvæ varying little in size and evidently belonging to a single brood. In one $\log$, however, we found a pair of the beetles guarding a batch of about 40 large, olive-green, broadly elliptical eggs, some of which had just hatched. The young larvæ closely resembled the older individuals in the structure of the peculiarly modified paw-like metathoracic legs, which are rubbed over the finely ridged middle coxæ during stridulation, but the hairs on the body were conspicuously longer and coarser. Our observations on the beetles and their larvæ both in the field and in the laboratory, confirm the statements of Ohaus.

The preceding account of the Platypodids, Scolytids and Passalids will suffice to show that they have reached a more advanced stage of social development than Coccidotrophus and Eunausibius, though the latter exhibit certain interesting resemblances to such ambrosia beetles as Xyloterus. The two Silvanids really represent a stage in social development intermediate between that of the families mentioned and the merely gregarious Silvanus, Oryzrphilus, Nausibius etc. Although the colonies of Coccidotrophus and Eunausibius are founded by pairs of parent beetles and in the climax stage of their development may comprise a considerable number of offspring in all stages of development, yet the latter do not seem to be the recipients of any special care on the part of the parents, unless we interpret as such the guarding of the petiolar cavity and the deepening of the food-grooves which would seem to render the nutritive parenchyma more accessible 
to the larvæ. And although all the members of the colony, beetles and larvæ alike, seem to be very indifferent to one another, except when they are competing for the honey-dew of the same coccid or when larvæ occupy cocoons in process of construction by other larvæ, yet under normal conditions there are no signs of hostility on the part of the beetles and larvæ even when other individuals are very annoying. Moreover, the use of the petiolar cavity as a common domicile, with its kitchenmiddens and more or less definite arrangement of the frass-ridges and wall about the entrance, the droves of coccids and the definite orientation of the eggs and cocoons, all show a much more socialized condition than anything that has been hitherto observed in other Cucujids. I believe, therefore, that I am justified in regarding the two Tachigalia Silvanids as representing a fourth group of social beetles, of a more primitive type than any of the three families above considered and differing in the absence of any definite preparation of larval food by the parents. No such preparation is necessary, in fact, owing to the peculiar conditions under which the Coccidotrophus and Eunausibius live, since both the young and the adults feed on the same substances and these are furnished by the plant and the coccids, which in turn feed on the same specialized parenchyma as the beetles.

No cioubt the toleration by the beetles and larvæ of such different insects as the coccids, the Scymnus larvæ, the larval and adult Diadiplosis, the Entomobrya, Aphiochaeta and probably also of the adult Blepyrus, is due to the same causes as the toleration by so many ants and termites of numerous myrmecophiles and termitophiles. Such guests, parasites and synoeketes can, of course, manage to live only among insects which through long association with individuals of their own species have come to tolerate or even to seek the presence of insects belonging to alien, or unrelated species.

\section{2.-The Development of the Feeding-Habits of THE Social Silvanids.}

There would seem to be little doubt that the primitive food of Coccidotrophus and Eunausibius is the nutritive parenchyma of the Tachigalia petioles. But this is a very specialized diet 
compared with that of other Silvanidæ. Although such genera as Silcans, Oryzaphilus, Cathartus and Nausibius eat by preference regetable substances with high protein, starch or sugar content, none of these forms is known to devour the tissue of growing plants, and it is even doubtful whether White's statement (1872) that the Cucujid Dendrophagus crenatus feeds on the inner bark of conifers, is correct (see Zoologica III, No. 5). The Tachigalia beetles are primarily attracted by the tree and there is every reason to regard this peculiar Leguminous plant as their only host, so that in this respect, also, they are highly specialized, for while some of the Silvanids, Lemophloeids and Cucujids (sens. str.) prefer particular trees, they seem nevertheless to thrive equally well in trees of different species, probably because they do not eat the living plant tissues but merely require special moisture conditions or the presence of certain other insects. We must suppose, furthermore, that the social Silvanids are primarily attracted to the Tachigalia by certain chemical substances in the petioles, a supposition which seems to offer the only satisfactory explanation, as Picard (1919) has shown, for the selection of particular host plants by particular insects. We should have to suppose also, that the beetles can discriminate between the petiolar substances of young shade-and older sun-trees, since they confine their attentions to the former. This is not surprising when we consider that some insects, e.g., certain Cynipid gall-flies exhibit even more delicate powers of discrimination since, when ovipositing, they seem to be able to distinguish between the viability of different buds or leaves on the same branch.

An even more interesting problem is presented by the coccidophily of Coccidotrophus and Eunausibius, for nothing like it has been observed in any other beetles, and apart from the ants, few insects are known to have developed the ability to solicit honey-dew from any of the Homoptera. I find only the two following cases in the literature, the first an observation by Belt in his "Naturalist in Nicaragua" (1884, p. 228), on wasps attending Membracids: "Similarly as, on the savannahs, I had observed a wasp attending the honey-glands of the bull's horn acacia along with the ants, so at Santo Domingo another wasp, belonging to quite a different genus (Nectarinia), attended some 
of the clusters of frog-hoppers, and for the possession of others a constant skirmishing was going on. The wasp stroked the young hoppers, and sipped up the honey when it was exuded, just like the ants. When an ant came up to a cluster of leafhoppers attended by a wasp, the latter would not attempt to grapple with its rival on the leaf, but would fly off and hover over the ant; then when its little foe was well exposed, it would dart at it and strike it to the ground. The action was so quick that I could not determine whether it struck with its fore-feet or its jaws, but I think it was with the feet. I often saw a wasp trying to clear a leaf from ants that were already in full possession of a cluster of leaf-hoppers. It would sometimes have to strike three or four times at an ant before it made it quit its hold and fall. At other times one ant after the other would be struck off with great celerity and ease, and I fancied that some wasps were cleverer than others. In those cases where it succeeded in clearing the leaf, it was never left long in peace. Fresh relays of ants were continually arriving, and generally tired the wasps out. It would never wait for an ant to get near it, doubtless knowing well that if its little rival once fastened on its leg, it would be a difficult matter to get rid of it again. If a wasp first obtained possession, it was able to keep it; for the first ants that came up were only pioneers, and by knocking these off, it prevented them from returning and scenting the trail to communicate the intelligence to other's."

The second case is more remarkable and refers to a Gerydine Lycænid butterfly of India, described by Bingham (1907, p. 287) : "A remarkable habit in one member" of the subfamily, viz., Allotinus horsfieldi, has been communicated to me by Colonel H. J. Barrow, R. A. M. C. He writes: 'I don't know whether you have observed the habits of a small plain butterfly which I caught in Maymyo. I watched it often in the jungle, sometimes for an hour at a time. It puzzled me at first to know why it took such an immense time to settle. It would keep within one yard of a spot and almost settle, twenty times perhaps, before it actually did. Its legs are immensely long and I discovered why. It settles over a mass of Aphides and then tickles them with its proboscis, just as ants do with their antennæ and seems to feed on their exudations,' The butterfly would settle over rather large ants 
that were attending the aphids 'and did not mind one or two actually standing up and examining its legs to see who was there. The ants did not attack it in any way." "

A comparison of the behavior of the insects considered in the foregoing paragraphs is very instructive. The predilection of ants for various Homoptera (aphids, coccids, membracids, cercopids and psyllids) is well known. Though never observed among the predatory Dorylinæ and Cerapachyinæ and rare among the Ponerinæ and Pseudomyrminæ this predilection is, nevertheless, so prevalent among the higher subfamilies (Myrmicinæ, Dolichoderinæ and Formicinæ) that it has not escaped the most casual observer. When this type of behavior is highly developed, as in our species of Lasius, the ants display not only an exquisite deftness in stroking their trophobionts but also a decidedly proprietary interest in them, most clearly evinced by building peculiar carton or earthen shelters over them, aggressively aefending them from their foes, or even collecting them and their eggs in the nests, distributing them over the surfaces of suitable plants and conveying them to places of safety when the colonies are disturbed. The whole performance is so elaborately adaptive as to suggest on the part of the ants an intimate acquaintance with the requirements and habits of their wards. This is also indicated when the latter fail to respond to stroking, for the ants do not wear themselves out by prolonged solicitation after their cattle have discharged their honey-dew, but stand around as if waiting for more of the saccharine liquid to accumulate.

The wasp described by Belt and the butterfly described by Bingham are really robbers, the former having learned to dispossess the ants of their wards, at least temporarily, the latter to overreach the ants and obtain the honey-dew by stealth. Though very different, the relations of the beetles to their coccids are no less extraordinary. The case is, indeed, so far as known, unique among the Coleoptera. Unlike many species of ants, the beetles have not yet learned to pick up the coccids and carry them about, but merely accept them as an integral part of the normal environment or as members of the colony. The fact that the beetles clearly recognize the signal of the prospective emission of the honey-dew by the coccids, when they raise their caudal segments, 
and the fact that they devote more attention to the posterior than to the anterior end of the larger coccids, implies a delicate discrimination, because both ends of the coccid's body are so very much alike. Furthermore, the beetle's antennæ and mouthparts seem to be so clearly adapted to dealing with the coccids as to indicate that the trophobiotic relations between the two species have been in existence for a very long time. The beetle's extraordinary perseverence in stroking individual coccids after they have been exhausted by repeated emissions of honey-dew might be interpreted either as a very thorough and hence highly adaptive method of exploiting the coccids, or as due to a very imperfect discernment of their physiological peculiarities.

Obviously the most remarkable item of behavior in Coccidotrophus and Eunausibius is the stroking of the coccids by the larvæ of all stages, as well as by the adult beetles. No one has even considered the possibility of a similar performance by the larvæ of ants, wasps or butterflies, since it is difficult to imagine creatures more unfitted for such behavior. Nevertheless, Mr. W. F. Fiske informs me that while he was investigating certain injurious insects in British East Africa, he saw small worker ants climbing a tree with their larvæ and holding them to the posterior ends of aphids, so that they could feed on the honey-dew voided in response to the antennal solicitations of their nurses! Unfortunately no specimens of the ants were preserved, and from Mr. Fiske's description I am unable to determine even the subfamily to which they belonged, but I have no reason to doubt the statement of an entomologist so competent and so keenly observant. I surmise that the ant must have been some Myrmicine which is unable to feed its larvæ by regurgitation, as otherwise such behavior would be superfluous.

So specialized a habit as the coccidophily of the two genera of social Silvanids calls for some consideration of its possible phylogenetic origin. Under existing conditions, the beetles either find the coccids already established in petioles that have been previously inhabited by other beetle colonies or by other insects, or the coccids enter the young petioles just after they have been perforated by the beetles, for insects with sucking mouthparts cannot, of course, gain access to the cavities in any other way. That they migrate into the petioles as very young individuals is 
certain. Later, after completing their growth, they are often too bulky to escape through the entrances made by the beetles, and as such imprisoned coccids contain eggs, they might be supposed to breed in the petioles. I have never been able to find either the males or the deposited eggs in the petioles, and as the total number of coccids in a petiole is too small to indicate the survival of many of the young, I suspect that the beetles, though averse to devouring the young or mature coccids, nevertheless consume many of the eggs. How the coccids manage in the first place to reach the individual Tuchigalia plant is a problem which presents itself also in the case of any of the other often widely distributed species of the family. That ants have much to do with carrying certain species of coccids to their host-plants is very probable. The only other active agents in such distribution would seem to be birds or the wind.

Soon after they enter the petioles the coccids seek out the strands of nutritive parenchyma, and sink their slender beaks into the tissue. And as the beetles keep gnawing at the same strands, grooves or narrow depressions are soon made in which the coccids settle, one behind the other, in rows, with the long axes of their bodies parallel with the long axis of the petiole. Thus the coccids naturally and inevitably come to lie in the paths of the feeding beetles, so that these can hardly avoid continual contact with the waxy creatures and their excrement. Probably at first the coccids simply voided their excrement in the grooves, thus drenching the surface of the nutritive parenchyma, so that the beetles found their bread spread with syrup. But this could hardly be an unalloyed blessing, because a sticky liquid spread on the walls of the petiole would almost certainly be injurious or fatal to the eggs, pupæ and younger larvæ of the beetles. We may therefore conjecture that the latter soon learned to stroke the coccids and to swallow the honey-dew at its very source, and that they have even acquired so keen an appetite for the liquid that it has now become a very important if not an essential constituent of their diet. The exploitation of such a constant and energizing supply of syrup, moreover, would surely tend not only to lengthen the original life-span of the adult beetles but also to increase the number of their progeny and hence the size and vigor of their colonies. This is suggested by the conditions 
in certain ants, $\epsilon . g$., our yellow, hypogæic species of Lasius, which are able to develop populous colonies mainly, if not exclusively, on a diet of honey-dew derived from root-aphids and rootcoccids.

Inasmuch as the larvæ, from their very youngest stages, no less than the adult beetles, continually stroke the coccids, the question arises as to whether the habit was first acquired by the larvæ, or by the beetles, or whether both instars developed it simultaneously. An answer to this question might, perhaps, be forthcoming if we could determine whether the larva or the adult beetle shows the greater structural adaptation of the antennæ and mouthparts to dealing with the coccids. The larvæ as I have shown, use both their antennæ and maxillæ in the process, the adults only the antennæ, but although the beetles are able to cover a greater area of the coccid's surface with their antennal clubs, the larger larve at least, by combining both pairs of organs, can probably produce a stimulus no less intense and effective. The larvæ are certainly more alert, restless and inquisitive than the beetles and the mandibles in the youngest stages seem to be very poorly adapted to feeding on the nutritive parenchyma. It is therefore quite as probable that the habit of stroking the coccids was first acquired by the young larvæ and later continued in the adult as that it originally appeared in the latter and was inherited in earlier and earlier ontogenetic stages till it came to be manifested by the just-hatched larva less than a millimeter in length. As shown by the observations recorded on p. 70 such larvæ show an even greater avidity for the honey-dew than the adult beetles. Since the stroking of the female beetle by the male during the courtship is precisely like the stroking of the coccids, we might be tempted to conjecture that the habit had arisen first in the adult as a modification of the sexual appetite, but this is, perhaps, rather far-fetched.

\section{3.-The Building of THE Cocoon.}

The few data I have been able to gather concerning the processes accompanying pupation in the beetles allied to Coccidotrophus and Eunausibius are reproduced in Zoologica III, No. 5. The pupating larvae of some Læmophloeids, Silvanids and Cucu- 
jids are described as attaching themselves by the last segment to the substratum, and pushing back the larval skin to the tip of the abdomen which remains fixed to the exuvium. In Oryz $x$ philus surinamensis the larva before pupating makes a rude cocoon by agglutinating particles of food or detritus with an oral secretion, but I have seen no circumstantial account of the process which may be of considerable interest in connection with the cocoon-building of coccidotrophus. The Cucujus larva also makes a rude cocoon (see p. 177).

The construction of a substantial cocoon by the larvæ of the social Silvanids would seem to be necessary, because a nude pupa, even if attached to the petiolar wall by its anal end, would be exposed to injury by the numerous beetles and larvæ moving about in the narrow cavity. But the way in which the cocoon is constructed is, to say the least, very unusual. So far as known, the larvæ of Coleoptera and other insects, when engaged in making such structures, remain in situ and build the cocoon as an envelope around the body, using for the purpose extraneous particles of earth, detritus, wood or frass, or threads of silk spun from the sericteries or more rarely a secretion of the Malpighian tubules, as in ant-lions and certain weevils, as described by Knab (1915a, 1915b) and others, or several secretions as described by Böving for Donacia (1910). The Coccidotrophus larva, however, laboriously collects minute particles of living plant-tissue, mixes them with saliva and builds them up in a very definite manner, repeatedly leaving the structure to go afield for the purpose of collecting the necessary materials. When the cocoon is all but completed the larva enters, and becoming a voluntary prisoner, closes the aperture at the end with materials scraped from the inner surfaces of the walls. I have failed to find in the entomological literature any account of such a method of cocoon-building, which in many particulars resembles the nest-building of certain birds and rodents.

The only suggestion I can make in regard to the possible origin of this behavior is that it may be derived in some way from the beetle's habit of building up its frass in more or less regular ridges, or welts between the food-grooves or immediately around the entrances to the petioles. I have been unable actually 
to witness this performance as the beetles never exhibited it after the petioles were cut open. I am inclined to believe that the feces are not simply voided in the spaces between the foodgrooves but actually built up with the aid of the mouthparts. 'This seems to be clearly indicated by the circular wall around the entrances (Fig. 11). Perhaps the larvæ have quite as much to do with the construction of the ridges as the beetles.

\section{4.-Concluding Remarks On the Behavior of the SOCIAL SilvaNids}

All modern observers of insects have been deeply impressed by the highly mechanized character of their behavior, but it is equally true that those who have most closely studied these organisms both under natural and experimental conditions have failed to find that the behavior of any one of them can be completely reduced to a rigid system of automatic or stereotyped reactions. While the behavior of certain forms such as the larval ant-lion, according to Doflein (1916) or the larval wormlion (Vermileo), as shown by my unpublished studies, seems to consist almost entirely of a small number of reflexes, the behavior of other insects, such as the solitary wasps, termites and social Hymenoptera, often exhibits considerable plasticity, modifiability or adaptability. Between these extremes we find the majority of insects with a certain modicum of the latter type of behavior. To this group we may assign the social Silvanids. The interpretation of their various activities necessarily involves some reference to the behavior of insects in general and the assumption of a definite attitude towards certain intricate and much discussed questions. The limitations of space compel me, therefore, either to leave the whole matter unconsidered or to treat it in a very brief and sketchy manner. I prefer to adopt the latter course.

The fashion which required one to explain as much as possible of the behavior of an insect in terms of tropisms, or taxes, and measured the value of one's work by the success achieved in the endeavor, seems to be rapidly passing. Thirty years ago I followed the fashion with some enthusiasm, but continued observation of the ways of insects has made me very 
dubious in regard to the whole subject of the tropisms. My present position concerning them is not essentially clifferent from that of Jennings (1904, 1906, 1909), von Buddenbrock (1915), Claparède (1912, 1913), and others. I should, therefore, interpret them as adaptive, secondarily developed reflexes and not as unique, primitive elements in the genesis of instinctive behavior.

There are, nevertheless, in the behavior of Coccidotrophus certain phenomena, which some might be inclined to interpret as tropisms, especially the reactions to contact, light and chemical stimuli. The reader who has followed my account of the beetle will have noticed the peculiar orientation of some of its stages and of some of the associated insects with respect to the walls of the long fusiform petiolar cavity which they inhabit. Thus the eggs, cocoons and pupæ of the beetle are always placed with their long axes parallel with the long axis of the petiole, and the coccids, while feeding, the cocoons of Blepyrus, which are formed within the bodies of the coccids, and the nude pupæ of Scymnus assume the same orientation. The food grooves which are excavated by the beetles and the frass-ridges which they build, as well as the longer axis of the entrance are all longitudinal. Moreover, the heetles spend much time lying in the foodgrooves with their narrow bodies longitudinally oriented and with as much as possible of their surface in contact with the floor and walls of the grooves.

At first sight this striking series of orientations would seem to be best described as tropistic, perhaps as due to some form of thigmotropism, but it is eviclent that the only behavior which might be legitimately regarded as such is that of the adult beetie when resting or moving in the food grooves. The Collembolans and the larvæ of Scymmus and Diadiplosis exhibit not the slightest tendency to assume a similar orientation, and the Coccidotrophus larvæ show no traces of it till they start their cocoons. Even then, though they orient their cocoons, they assume a position with their long axes parallel with the long axis of the petiole only while actually adding particles to the walls and after they have pupated. It is evident, furthermore, that nearly all the orientations mentioned can be traced more or less directly to peculiarities in the structure of the petiole, i.e., to the shape of 
its cavity and the histological structure of its walls, and especialiy to the singular arrangement of the nutritive parenchyma in long, narrow strands. The beetles gnaw these out and thus form grooves, which in turn orient the coccids and their internal parasites. The orientation of the frass ridges and beetle cocoons is also determined by the grooves, and the position of the Coccidotrophus eggs is very probably due to their being laid and attached by the beetles while they are lying in the depressions between the frass ridges. Thus the various orientations are merely so many direct or indirect adaptations to the nutritive parenchyma and the long narrow petiolar cavity. The latter clearly determines to some extent the longitudinal arrangement of the bulky cocoons, just as a long Pullman car makes it advisable for us to arrange the berths in a similar manner.

One orientation, that of the entrance, is not so easily explained. In all the petioles I have examined, the long axis of the entrance is parallel with the long axis of the petiole. It is evident that it precisely fits the head of the beetle and that the latter while gnawing it must stand on the outer surface of the petiole at right angles to its long axis. When the surface is longitudinally grooved, as is sometimes the case, the entrance can, of course, have no other orientation, but often the surface is quite smooth and it is difficult to see why it should be easier for the insect to gnaw through the tissue lengthwise rather than crosswise of the grain. It is also evident that while guarding the entrance the beetle has its long axis at right angles to the long axis of the petiole, but since a tubular wall is built around the insicle of the orifice (Fig.11) the insect's reaction might be regarcled as thigmotropic, like its reactions to the walls of the food grooves.

Nevertheless, I am convinced that the responses of the adult beetle to contact stimuli may be more properly interpreted as typical and highly adaptive reflexes. This is clearly indicated by the structure of the insect. The long, parallel-sided, subcylindrical form of the body and the shortness of the legs are merely so many adaptations to living in narrow tubular cavities. The same type of structure reappears as an independent development in each of many different families of beetles, which live in cylindrical cavities or burrows, e.g., the Scolytidæ, Platypodi- 
dæ, Brenthidæ, Bostrychidæ, Buprestidæ (Agrilus), Cleridæ, Trogositidæ, Histeridæ (Teretrichus), Colydiidæ (Colydium), Lyctidæ, Lucanidæ (Ceruchus), Elateridæ, Parandridæ, many Cerambycidæ, Lymexylondidæ, etc. This type of body and one more extremely flattened and adapted for living under bark (Cucujus, Brontes), are very common among the Cucujidæ seirs. lat. The peculiar conformation of the front and of the mandibles of Coccidotrophus and Eunausibius, so strikingly like that of many ants (Cryptocerus, Cataulacus, Colobopsis, etc.) is, moreover, a definite adaptation to guarding elliptical or circular entrances to solid-walled nesting cavities. It is interesting to note also that the general shape of the body of Coccidotrophus and Eunausibius reappears in several genera of ants which regularly live in narrow plant cavities, e.g., Colobopsis, Simopone, Cylindromyrmex, Metapone, Pachysima, Tetraponera and Pseudomyrma (see Plate III, figs. 1 and 2). Even the larvæ and pupæ of these ants have assumed a similar form. (See Wheeler, 1918, and Wheeler and Bailey, 1920). We may say, therefore, that the whole general bodily structure of the various insects I have mentioned has been adaptively modified during their phylogenetic history and that such a modification can hardly be anything but an expression of a concomitant adaptation of their nervous system and reflexes.

Equally unsatisfactory from an ethological point of view is the reference of other behavioristic peculiarities of the social Silvanids to simple tropisms. Let us take as an example the attraction to the Tachigalia. I agree with Picard (1919) in his contention that phytophagous insects are attracted to their respective host-plants by particular chemical substances in the latter. Entomologists have always believed this but have usually described the phenomena as due to "odor" or "taste." To designate them as chemotropism really adds nothing to our knowledge but a technical term. The ethological question remains: Why is a particular insect species or sex attracted to a particular part of a particular species of host plant, or, in the case of the social Silvanids, why do they fly to and bore into the swellings of the petioles of young individuals of a certain species of Tachigalia? Undoubtedly the exquisite sense-organs in their antennal clubs enable the beetles to detect certain very delicate effluviæ emanat- 
ing from the young Tachigalia as a whole or perhaps even from the nutritive parenchyma in its petioles, but the attraction of these odors is probably due to their having acquired a "meaning" for the beetles, because the latter throughout their larval and early imaginal stages fed on these very substances, and had, in fact, long been familiar with the petiolar cavities, the coccids, etc. The latter part of this statement also applies to the young queens of the obligate Tachigalia ants of the genera Pseudomyrma and Azteca and would account for the rather unusual attachment of these insects to a definite host-tree. Hence in these cases organic memory, or "mneme," or even individual memory yields a more satisfactory explanation of the phenomena than a naked tropism.

A consideration of the responses to light leads to similar results. The beetle colonies, as we have seen are "photophobic," or live in the dark, and when the petioles are opened in the light the insects are at first much agitated but soon settle down and continue the regular routine of their existence even when the pieces of petiole are kept exposed to artificial or diffuse day-light in the laboratory. The adult beetles have well-developed eyes and the larvæ have three pairs of small simple eyes on each side of the head. (Plate VII, fig. 2, Plate VIII, fig. 10). And since a certain amount of light enters the petiole through the entrance, at least when it happens to be unguarded, it is probable that under ordinary conditions the eyes are mainly useful in enabling the insects and particularly the larvæ, to stay in the dark. There is nothing to show that the young beetles, which leave the petioles to establish new colonies, do so because they become positively phototropic. The emigration may, perhaps, take place at night and even if it occurs during the day the light in the parts of the jungle where the young Tachigalias are growing, is very subdued. I believe that the young beetles must emigrate either luecause the space in the petiole has become too greatly reduced by the growth of the colony or because the food-supply has for the same reason become insufficient. In either case emigration would be due to internal stimuli ("physiological states"). These may also be important factors in the swarming of ants, bees and termites. We might, perhaps, even suppose that the guarding of the entrance by the beetles is due to an abortive or inhibited emigration impulse due to feebler or vaguer internal stimuli 
comparable with those which sometimes impel a person who has been sitting for hours in a dimly-lighted room, to stand at the window or open door or to step out into the sunlight.

Thus while it is easy to interpret many of the activities of the social Silvanids as adaptive reflexes it is difficult to assign to such stimuli as light, contact, chemicals, etc., the leading rôle which they have in the theories of Loeb and Bohn. Much of the behavior of the beetles, such as their treatment of the coccids, the building of the cocoon, mating, the guarding of the entrance, etc., so obviously depends on internal or physiological states that, in so far it has not become completely mechanized, we may more properly regard it as made up of cyclical activities like those recognized by Herrick (1910), Craig (1918) and others in birds. Craig especially has shown how much of the behavior of birds can be interpreted as cycles of appetence, or appetite and aversion, which he defines as follows: "An appetite (or appetence, if this term may be used with purely behavioristic meaning), so far as externally observable, is a state of agitation which continues so long as a certain stimulus, which may be called the appeted stimulus, is absent. When the appeted stimulus is at length received it stimulates a consummatory reaction, after which the appetitive behavior ceases and is succeeder br a state of relative rest. An aversion is a state of agitation which continues so long as a certain stimulus, referred to as the disturbing stimulus, is present; but which ceases, being replaced by a state of relative rest, when that stimulus has ceased to act on the sense-organs."

Rignano (1920) gives this same conception a more general physiological formulation in the following passage: "Every organism is a physiological system in a stationary condition and tends to preserve this condition or to restore it as soon as it is disturbed by any variation occurring within or without the organism. This property constitutes the foundation and essence of all "needs," of all "desires," of all the most important organic "appetites." All movements of approach or withdrawal, of attack or flight, of taking or rejecting which animals make are only so many direct or indirect consequences of this perfectly general tendency of every stationary physiological condition to remain constant. We shall soon see that this tendency in its 
turn is only the direct result of the mnemic faculty characteristic of all living matter. This single physiological tendency of a general kind, accordingly, is sufficient to give rise to a large number of the most diversified particular affective tendencies. Thus every cause of disturbance will produce a corresponding tendency to repulsion with special characteristics determined by the kind of disturbance, by its strength, and by the measures capable of avoiding the disturbing elements; and for every incidental means of preserving or restoring the normal physiological condition, there will be a quite definite corresponding tendency such as "longing," "desire," "attraction" and so forth. Even the instinct of self-preservation-when understood in the usual narrow sense of "preservation of one's own life"-is only a particular derivative and direct consequence of this very general tendency to preserve physiological invariability." This tendency, however, as Rignano remarks, is supplemented by another, "for as soon as the previous stationary condition cannot be restored by any means, that is by any movements or change or Iocation, the organism disposes itself in a new stationary condition consistent with its new external and internal environment. In this way there originate a large number of new phenomena called 'adaptations'."

Of course, the contention that the appetites are fundamentally important in animal behavior is not new. It is merely astonishing that they have been so consistently ignored by many modern observers. The róle of appetency, or appetite, was set forth with great acumen by the philosopher Fouillée, especially in the third book of his "Evolutionnisme des Idées Forces" (1920, first edition 1890). The germ of the conception, however, can be traced back to Reimarus (1798) and Leibnitz (Dwelshavers, 1908 , p. 181), to the "appetitus sensitivus" of the schoolmen

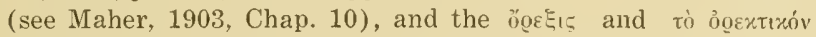
of Aristotle (De Anim. 3, 10; Eth. Nic. 1, 13, 18). Recently the behavioristic psychologists, psychopathologists and students of the sympathetic nervous system and internal secretions, Mosso (1899), Drever (1917), Smith and Guthrie (1921), Goddard (1919), Kempf (1918), Crile (1915), Cannon (1915), and others, have emphasized the importance of the appetites and others have stressed their peculiarities in such terms as "tumescence" and 
"detumescence" in sexual psychology and "enhancement," "relief" and "catharsis" in art. Kempf (1921) in his valuable contribution to psychoanalysis has used the term "craving" instead of appetite, avoiding the "libido" of the Freudians which embodies the same notion. In a recent volume ${ }^{1}$ Bertrand Russell takes essentially the same view of the phenomena of appetite but uses the word "desire." Most of the authors cited deal, of course, with man, but one can hardly overestimate the value of their work for the animal behaviorist and entomologist. It is certain that insects have well-developed sympathetic and glandular systems and that their alimentary and sexual behavior presents quite as definite a picture of appetites as does the corresponding behavior of the higher animals.

Fouillée believes that every appetition involves a rudimentary cognition and that automatic behavior like that of the habits and reflexes is merely lapsed appetition. If it could be shown that the latter really can have this derivation and that such ontogenetic mechanisms as habits can acquire representation in the germ-plasm and hereditary transmission, we might be in a position to give a consistent account of all animal behavior, and one which would lead us to regard the reflexes and the tropisms as ultimate, highly specialized end-stages instead of primitive, elemental components of behavior.

"'The Analysis of Mind," London and New York, Allen, Unwin \& Macmillan, 192I.

\section{POSTSCRIPT.}

Just as the final proof of this paper was being returned to the printer Prof. I. W. Bailey received a letter from Col. David Prain, Director of the Royal Botanical Gardens of Kew, with the identification of the Tachigalia. It proves to be T. paniculata Aublet. Col. Prain compared our specimens with Aublet's type in the British Museum Herbarium.

Among the various social beetles considered in the latter part of my paper I should have included Phrenapates bennetti Kirby, the habits of which were studied by Ohaus (1909) in Ecuador. I shall have occasion to return to this insect in a future publication. 


\section{BIBLIOGRAPHY}

AUBLET.

1775. Histoire des Plantes de la Guiane Françoise. 4 vol., 1775. London and Paris, Didot.

BELT, T.

1888. The Naturalist in Nicaragua. 2d Ed. London, Bumpus, 1888.

BinghaM, C. T.

1907. The Fauna of British India, including Ceylon and Burma. Butterflies. Vol. II, 1907, London, Taylor and Francis.

Blatchley, W. S.

1910. An Illustrated Descriptive Catalogue of the Coleoptera or Beetles (Exclusive of the Rhynchophora) Known to Occur in Indiana. Indianapolis, Nature Publ. Co., 1910.

BLISSON, J. F. J.

1849. Description de la Larve et de la Nymphe du Silvanus sexdentatus Fabr. Ann. Soc. Ent. France (2) 7, 1849, pp. 163-172, pl. 6, figs. 1-18.

Bodine, J. H.

1920. Factors Influencing the Water Content and the Rate of Metabolism of Certain Orthoptera. Journ. Exper. Zool. 32, 1921 , pp. $137-164,6$ figs., 6 tables.

BöviNG, A.

1910. Natural History of the Larvæ of Donaciinæ. Internat. Rev. gesamt. Hydrobiol. Hydrograph. 3, 1910, pp. 45-108. Biol. Suppl., pp. 1-4, 7 pls. and 70 textfigs.

VON BUDDENBROCK, W.

1915. Die Tropismentheorie von Jacques Loeb. Biol. Centralbl. 36, 1915, pp. 481-506. Trans. in Journ. Anim. Behav. 6, 1916, pp. 341-366.

CANNON, W. B.

1915. Bodily Changes in Pain, Hunger, Fear and Rage. N. Y. and London, D. Appleton \& Co., 1915.

CASEY, T. L.

1884. Revision of the Cucujidre of America North of Mexico. Trans. Amer. Ent. Soc. 11, 1884, pp. 69-112, 5 pls.

Champion, G. C.

1896b. Silvanus surinamensis (Linn.) Ent. Month Mag. (2) 7, 1896, pp. $268,269$.

Chittenden, F. H.

1895. The More Important Insects Injurious to Stored Grain. Yearbook U. S. Dep. Agric. (1894) 1895, pp. 377-394. 9 figs.

1896. A New Grain Beetle. Canad. Ent. 28, 1896, pp., 197, 198.

1897a. Some Insects Injurious to Stored Grain. Farmers' Bull. No. 45. U. S. Dep. Agric., 1897, pp. 1-24, 18 figs.

1897b. Some Little-known Insects Affecting Stored Vegetable Products. Bull. No. 8 (N. S.) U. S. Dep. Agric. Div. Ent., 1897, pp. $1-45,10$ figs.

1911. A List of Insects Affecting Stored Products. Bull. No. 96, Pt. 1, U. S. Dep. Agric. Bur. Ent., 1911, pp. 1-7. 
Claparède, E.

1912. Point de Vue Physico-Chimique et Point de Vue Psychologique. Scientia 11, 1912, pp. 251-258.

1913. Article "Thierpsychologie" in "Handwörterbuch der Naturwissenchaften". Bd. 9, Jena, Gustav Fischer, 1913.

Comstock, J. H.

1882. Note on the Structure of Mealy Bugs. Rep. U. S. Dep. Agric.

COQuerel, C. (1881), 1882, p. 214.

1849. Note sur les Métamorphoses du Silvanus sexdentalus. Ann Sac. Ent. France (2) 7, 1849, p. 172.

Craig, W.

1918. Appetites and Aversions as Constituents of Instincts. Biol. Bull. 34,1918 , pp. $91-107$.

Craighead, F. C.

1920. Biology of Some Coleoptera of the Families Colydiidæ and Bothrioderidæ. Proc. Ent. Soc. Wash. 22, 1920, pp. 1-13, 2

Crile, G. W. pls., 1 textfig.

1915. The Origin and Nature of the Emotions. Phila. and London, W. B. Saunders Co., 1915.

DiммосK, Mrs. A. K.

1885. The Insects of Betula in North America. Psycise, 1885, pp. 239-243, 271-286.

DIM MOCK, G.

1884. Article "Beetles" in Standard Natural History. Vol. 2, 1884. Boston, S. C. Cassino \& Co.

DOFLEIN, F.

1916. Der Ameisenlöwe, eine biologische, tierpsychologische und reflexbiologische Untersuchung. Jena. Gustav Fischer, 1916, 138 pp., 43 figs., 10 pls.

DORAN, E. W.

1892. The Evolution of Heat by Silvanus cassia. Proc. Ent. Sac. Wash. 2, 1892, pp. 325-327.

DREVER, J.

1917. Instinct in Man, a Contribution to the Psychology of Education. Cambridge, Univ. Press, 1917.

DWelshauvers, G.

1908. La Synthèse Mentale. Paris, F. Alcan, 1908.

EICHOFF, W.

1881. Die Europäischen Borkenkäfer. Berlin, J. Springer, 1881, pp. 280-281.

EMERY, C.

1893. Studio Monografico sul Genere Azteca Forel. Mem. R. Accad. Sc. Ist. Bologna (5) 3, 1893, pp. 319-352, 2 pls.

ESCHERICH, K.

1902. Biologische Studien über algerische Myrmekophilen, zugleich mit alIgemeinen Bemerkungen über die Entwicklung und Bedeutung der Symphilie. Biol. Centralbl. 22, 1902, pp. $638-663,4$ figs. 
FELT, E. P.

1911a. A Generic Synopsis of the Itonidæ. Journ. N. Y. Ent. Soc. 19, 1911, pp. 31-62.

1911b. Habits and Galls of American Gall Midges. Journ. Econ. Ent.

Fiske, W. F. 4,1911 , pp. $451-484$.

1905. Catogenus rufus. A Coleopterous Parasite. Proc. Ent. Soc. Wash. 7, 1905, pp. 90-92.

Forbes, S. A.

1880. Studies of the Food of Birds, Insects and Fishes Made at the Illinois State Laboratory of Natural History at Normal, Illinois. Bull. Ill. State Lab. Nat. Hist. 1, 1880 (second ed. 1903), 176 pp.

1884. Insects Injurious to the Strawberry. Rep. State Ent. Illinois 13,1884 , pp. $60-180$.

1894-1905. A Monograph of the Insect Injuries to Indian Corn. Part I, 18th Rep. State Ent. Illinois, 1894, 171 pp., 15 pls. Part II, ibid. 23rd Rep. 1905, 273 pp.

1915. The Ecological Foundations of Applied Entomology. Ann. Ent. Soc. Amer. 8, 1915, pp. 1-19.

FOREL, A.

1904. In und mit Pflanzen lebende Ameisen aus dem AmazonasGebiet und aus Peru. Zool. Jahrb. Abth. Syst. 20, 1904, pp. 677-707.

1906. Fourmis Néotropiques Nouvelles ou peu Connues. Ann. Soc. Ent. Belg. 50, 1906, pp. 225-249.

1912. Formicides Néotropiques. Part IV. Mém. Soc. Ent. Belg. 20, 1912, pp. $1-32$.

Fouillée, A.

1920. L'Évolutionnisme des Idées-Forces. 6th Ed. Paris. F. Alean, 1920 (First ed. 1890).

FOWLER, C.

1889. The Coleoptera of the British Islands. Vol. III. Clavicornia London, L. Reeve \& Co., 1889.

GANGLBAUR, L.

1899. Die Käfer von Mitteleuropa. Bd. 3. Vienna, C. Gerold's Sohn, 1899.

GAVIT, J. E.

1849. Corn or Grain Weevil of Europe (Calandia granaria) and Silvanus surinamensis, the Weevil most Common in America. Trans. N. Y. State. Agric. Soc. for 1848. Vol. 8, 1849, pp. 656-662, plate.

Girault, A. A.

1912. Insects Injurious to Stored Grains and their Ground Products.

Bull. No. 156, Univ. Illinois Agric. Exper. Station, 1912, pp. $67-92,12$ figs.

GLOVER, T.

1869. The Food and Habits of Beetles. Rep. U. S. Com. Agric. 1868 (1869), pp. 78-117, 189 figs.

GODDARD, H. H.

1919. Psychology of the Normal and Subnormal. New York, Dodd, Mead \& Co., 1919. 
Grouvelle, A.

1896. Nitidulides, Colydiides, Cucujides et Parnides récoltés par M. E. Grouvelle au Brésil et autres Clavicornes nouveaux d'Amérique. Ann. Soc. Ent. France 65, 1896, pp. 177-216, 26 figures.

1913. Notes sur les Silvanini (Col. Cucujidæ). Ann. Soc. Ent. France 81,1913, pp. 313-386.

Guillebeau, F.

1890. Note sur les Silvanus. Rev. d'Ent. 9, 1890, pp. 220-224.

HAGEDORN, M.

1907. Pilzzüchtende Borkenkäfer. Naturw. Wochenschr. N. F. 6, 1907, pp. 289-293, 12 figs.

1910. Coleoptera. Fam. Ipidæ. Wytsman's Genera Insectorum, 1910, pp. $1-178,14$ pls.

HAMILTON, J.

1886. Natural History Notes on Certain Coleoptera. Canad. Ent. 18, 1886 , pp. $26-30$.

HaNDLIRSCH, A.

1908. Die Fossilen Insekten und die Phylogenie der Rezenten Formen. Text and Atlas. Leipzig, Wilh. Engelmann, 1908.

HARMS, H.

1906. Leguminosæ in II Beiträge zur Flora der Hylæa nach den Sammlungen von Ule's Amazonas-Expedition. Verh. bot. Ver. Prov. Brandenburg 48, 1906, p. 164.

HEIN, S. A. A.

1920. Technical Experiences in the Breeding of Tenebrio molitor. K. Akad. Vetens. Amsterdam. Proc. 23, 1920, pp. 193-218.

HERRICK, T, H.

1910. Instinct and Intelligence in Birds. Pop. Sci. Month., 1910, pp. 532-556, 82-97, 122-141.

Hopkins, A. D.

1898. On the History and Habits of the Wood Engraver Ambrosia Beetle Xyleborus xylographus (Say), Xyleborus saxeseni (Ratz), with Brief Descriptions of Different Stages. Canad. Ent. 30, 1898, pp. 21-29, 2 pls.

Howard, L. O. and C. L. Marlatt.

1896. The Principal Household Insects of the United States, with a Chapter on Insects Affecting Dry Vegetable Foods by F. H. Chittenden. Bull. No. 4, N. S., U. S. Dep. Agric. Div. Ent. 1896,130 pp., 63 figs.

HUBBARD, H. G.

1897. The Ambrosia Beetles of the United States. Bull. 7 (N. S.) Div. Ent. U. S. Dep. Agric. 1897, pp. 9-30, 34 figs.

1906. Ambrosia Beetles. Yearbook, U. S. Dep. Agric. 1906, pp. 421-430, 7 figs.

HUBER, J.

1908. Materiales para a Flora Amazonica. VII. Plantæ Duckeanæ austro-guyanenses. Bol. Mus. Goeldi 5, 1908, pp. 387, 388. 
JENNINGS, H. S.

1904. Contributions to the Study of the Behavior of Lower Organisins. Carnegie Inst. Wash. Publ. No. 16, 1904.

1906. Behavior of the Lower Organisms. New York, Columbia Univ. Press, 1906.

1909. Tropisms. C. R. 6me. Congrès. Internat. Psychologie Geneva, 1909 , pp. $307-324$.

KALTENBACH, J. H.

1874. Die Pflanzenfeinde aus der Klasse der Insekten. Stuttgart, Julius Hoffmann, 1874.

KEMPF, E.

1918. The Autonomic Functions and the Personality. Nervous and Mental Disease Monogr. Series No. 28. N. Y. and Washington, 1918.

KEMPF, E. J

1920. Psychopathology. St. Louis, C. V. Mosby Co., 1920.

KIEFFER, J. J.

1920. Déscription de quelques Cécidonyides Nouvelles. Marcellia 1, 1902 , p. 115.

KNAB, F.

1915a. The Secretions Employed by Rhynchophorous Larvæ in Cocoon-making. Proc. Ent. Soc. Wash. 17, 1915, pp. 154-158.

1915b. Dung-bearing Weevil-Larvæ. Proc. Ent. Soc. Wash. 17, 1915, pp. 193-194.

KOLBE, H.

1911. Die Vergleichende Morphologie und Systematik der Coleopteren Mem. 1me. Congr. Internat. d'Ent. Bruxelles, 1910. Vol. 2, 1911, pp. 41-68.

KÜSTER, E.

1911. Die Gallen der Pflanzen. Leipzig, L. Hirzel, 1911.

LEA, A. M.

1904. Descriptions of New Species of Australian Coleoptera. Proc. Linn. Soc. N. S. W. 29,1904 , pp. $60-107,1$ pl.

LEBARON, W.

1874. Fourth Annual Report of the Noxious and Beneficial Insects of the State of Illinois. Springfield, 1874, pp. 18-199. 94 figs.

LECONTE, J. L. ANd HORN, G. H.

1883. Classification of the Coleoptera of North America. Smiths. Misc. Coll, 507, 1883, pp. XXVIII, 567.

LENG, C. W.

1920. Catalogue of the Coleoptera of America North of Mexico. Mt. Vernon, N. Y., J. D. Sherman, 1920.

LUGGER, O.

1899. Coleoptera, or Beetles. Fifth Ann. Rep. Ent. Minnesota, 1899, $248 \mathrm{pp}$.

MacGlllivray, A. D.

1921. The Coccidæ. Urbana, Ill., Scarab Co., 1921. 
MAHER, M. (S. J.).

1903. Psychology, Empirical and Rational. London, Longmans, Green \& Co., 1903 .

MöвıUS, K.

1877. Die Auster und die Austernwirthschaft. Berlin, 1877. Transl. "The Oyster and Oyster Culture." Rep. U. S. Fish Comm. (1880), Part VIII, 1883, pp. 683-751.

Mosso, A.

1899. The Mechanism of the Emotions. Clark Univ. Decen. Cel. Vol., 1899, pp. 396-407.

NEGER, F, W.

1908a. Ambrosiapilze. Ber. Deutsch. Bot. Ges. 26, 1908, pp. 735-754.

1908b. Die Pilzkulturen der Nutzholzborkenkäfer. Centralbl. f. Bakteriol. 20, 1908, pp. 279-282.

1909. Ambrosiapilze II. Die Ambrosia der Holzbohrkäfer. Ber. Deutsch. Bot. Ges. 27, 1909, pp. 372-389.

1911. Zur Uebertragung des Ambrosiapilzes von Xyleborus dispar $F$. Naturw. Zeitschr. f. Forst. u. Landwiss. 9, 1911, pp. $223-225$.

NewComer, E. J.

1912. Some Observations on the Relations of Ants and Lycænid Caterpillars, and a Description of the Relational Organs of the Latter. Journ. N. Y. Ent. Soc. 20, 1912, pp. 31-36, 2 pls.

DE NICÈVILLE, L.

1890. The Butterflies of India, Burmah and Ceylon. 3. Calcutta, 1890.

OHAUS, F.

1899-1900. Bericht über eine entomologische Reise nach Zentralbrasilien. Stett. Ent. Zeitg. 60, 1899, pp. 204-245; 1900, pp. 164-191, 193-274.

1909. Bericht über eine entomologische Studienreise in Südamerika Stett. Ent. Zeitg. 70, 1909, pp. 3-139.

PACKARD, A. S.

1881. Insects Injurious to Forest and Shade Trees. Bull. No. 7, Dep. Inter. U. S. Ent. Cons., Washington, 1881, 275 pp. 100 figs.

PERRIS, E.

1852- 1862. Histoire des Insects du Pin Maritime. Ann. Soc. Ent. France (2) 10, 1852, pp. 491-522, pl. (3) 1, 1853, pp. 555-644;

2 , 1854 , pp. $85-160,593-646 ; 4,1856$, pp. $173-257,423-486$

5, 1857, pp. 341-395, pl. Suppl. (4) 2, 1862, pp. 173-243, pl.

1876. Larves de Coléoptères. Ann. Soc. Linn. Lyon. 22, 1786, pp. $259-418$.

DE Peyerimhoff, P.

1902.- 1903. Descriptions des Larves de Trois Coléoptères Exotiques. Ann. Soc. Ent. France, $71,1902-03$, pp. $710-718,6$ figs.

PICARD, F.

1919. Contribution a l'Etude du Peuplement d'un Végétal. La Faune Entomologique du Figuier. Ann. Serv. Epiphyt. 6, 1919, pp. $35-174$, 36 figs. 
Pierce, W. D.

1917. A Manual of Dangerous Insects Likely to be Introduced in the United States through Importations. U. S. Dep. Agric. 1917,256 pp., 48 pls., 107 text figs.

RED1, F.

1671. Experimenta circa generationem Insectorum. Amstelodami, 1671.

Rignano, E.

1920. Psychologie du Raisonnement. Paris, F. Alcan, 1920. (First Chapter translated and entitled "On the Mnemonic Origin and Nature of Affective Tendencies." Monist 221, 1911, pp. $321-356$.

REITTER, E.

1911. Fauna Germanica. Die Käfer des deutschen Reiches, III Bd. Stuttgart, K. G. Lutz, 1911.

REIMARUS, H. S.

1798. Allgemeine Betrachtungen über die Triebe der Thiere, hauptsächlich über ihre Kunsttreibe. Hamburg, C. E. Bohn, 1798.

RÜBSAMEN, E. K.

1899. Ueber die Lebensweise der Cecidomyiden. Biol. Centralbl. 19, 1899 , pp. $529,561$.

SCHNEIDER-ORELLI, F.

1911a. Die Uebertragung and Keimung des Ambrosia-Pilzes von Xyleborus (Anisandrus) dispar F. Naturw. Zeitschr. f. Forst- und Landwiss. 9, 1911, pp. 186-192, 223-225.

1911b. Ueber die Symbiose eines einheimischen pilzzüchtenden BorkenKäfers (Xyleborus dispar F.) mit seinem Nährpilz. Verh. Schweiz. Naturf. Gesell. 94, 1911, pp. 279, 280.

1912. Der unglejche Borkenkäfer (Xyleborus dispar F.) an Obstbäumen und sein Nährpilz. Naturwirtsch Jahrb. Schweiz. 1912, pp. $326-334$.

1913. Untersuchungen über den Pilzzüchtenden Obstbaumborkenkäfer $X$ yleborus (Anisandrus) dispar und seinen Nährpilz. Centralbl. Bakter. Parasit. 38, 1913, pp. 25-110.

SMith, J. B.

1909. The Insects of New Jersey. Ann. Rep. N. J. State Museum, 1909.

SMith, S. AND GUThrie, E.

1921. Chapters in General Psychology. Seattle, University of Washington Press, 1921.

SPRUCE, R.

1908. Notes of a Botanist on the Amazon and Andes. 2 vols. N. Y., Macmillan \& Co., 1908. (Chapt. 24, "Ants and Plant Structure," being a paper submitted and read to the Linn. Soc., Apr. 15,1869 , but not published.)

STitz, H.

1913. Ameisen aus Brasilien, gesammelt von Ule. Deutsch. Ent. Zeitschr. 1913, pp. 207-212, 2 figs. 
SuLC, K.

1909. Zur Anatomie der Cocciden. Zool. Anzeig. 34, 1909, pp. 164-172, 4 figs.

THAXTER, R.

1914. On Certain Peculiar Parasites of Living Insects. Bot. Gazette 58,1914, pp. $235-253,4$ pls.

1920. Second Note on Certain Peculiar Fungus Parasites on Living Insects. Bot. Gazette 69,1920 , pp. 1-27, 5 pls.

THOMANN, H.

1901. Schmetterlinge und Ameisen. Beobachtungen über eine Symbiose zwischell Lycrena argus L. und Formica cinerea Mayr. Inaug. Diss. Univ. Zürich, Chur, J. Casanova, 1901, 44 pp., $1 \mathrm{pl}$.

TUSLANE, L. R.

1844. Lègumineuses Arborescentes de l'Amérique du Sud. Arch. Mus. d'Hist. Nat. 4, 1844 , p. 160.

ULE, E.

1907. Ameisenpflanzen des Amazonasgebietes. In Karsten and Schenck's Vegetationsbilder 4. Reiche. Jena, 1907, 14 pp., $6 \mathrm{pls}$.

WASMANN, E.

1896. Die Myrmekophilen und Termitophilen. C. R. 3me Congr. Intern. Zool. Leyden (1895) 1896, pp. 411-440.

WEISSE, J.

1897. Biologische Mitteilungen. Deutsch. Ent. Zeitschr, 1897, pp. 389-395.

W HEELER, W. M.

1901. Microdon Larvæ in Pseudomyrma Nests. Psyche 9, 1901, pp. 222-224, 1 fig.

1918. A Study of Some Ant Larvæ, with a Consideration of the Origin and Meaning of the Social Habit among Insects. Proc. Amer. Philos. Soc. 57, 1918, pp. 293-343, 12 figs.

1921. A New Case of Parabiosis and the Ant Gardens of British Guiana. Ecology, 2, 1921, pp. 89-103, 3 figs.

WheEler, W. M. ANd Bailey, I. W.

1920. The Feeding Habits of Pseudomyrmine and Other Ants. Trans. Amer. Phil. Soc. N. S. 22, 1920 , pp. $235-279,5$ pls., 6 text-figs.

White, F. B.

1872. Contributions Towards a Knowledge of the Life-histories of Certain Coleoptera. Ent. Month. MIag. 8, 1872, pp. 196-198.

WickHaM. H. F.

1920. A Catalogue of the North American Coleoptera Described as Fossils. In Leng's Catalogue (q. v.) pp. 349-365. 



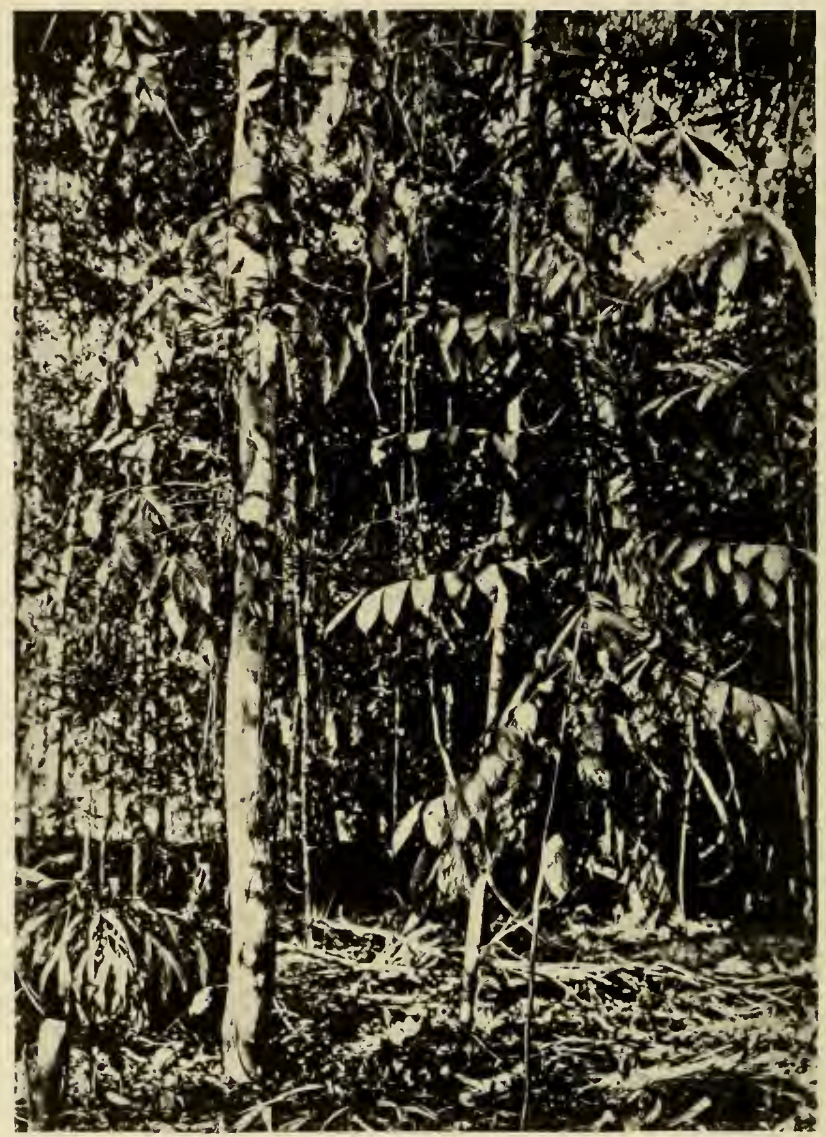

PLATE I. YOUNG TACHIGALIA FORMICARUM HARMS, FROM LETICIA, PERU.

From a photograph taken by $E$. Ule and reproduced from Plate $V$ of his article in Kartsen anrl Schrnck's Vegetationsbilder 1. Reihe, $1: 107$. 



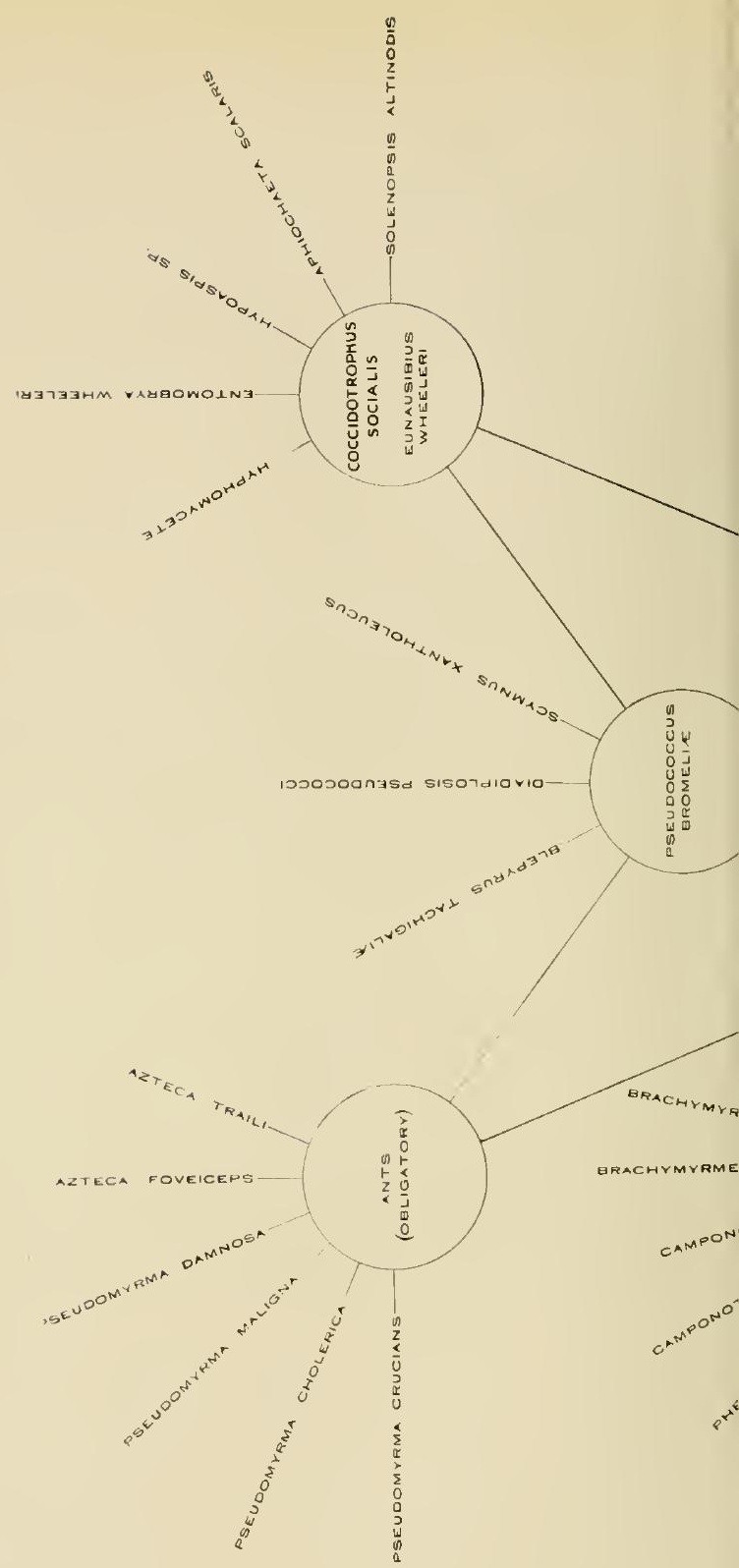




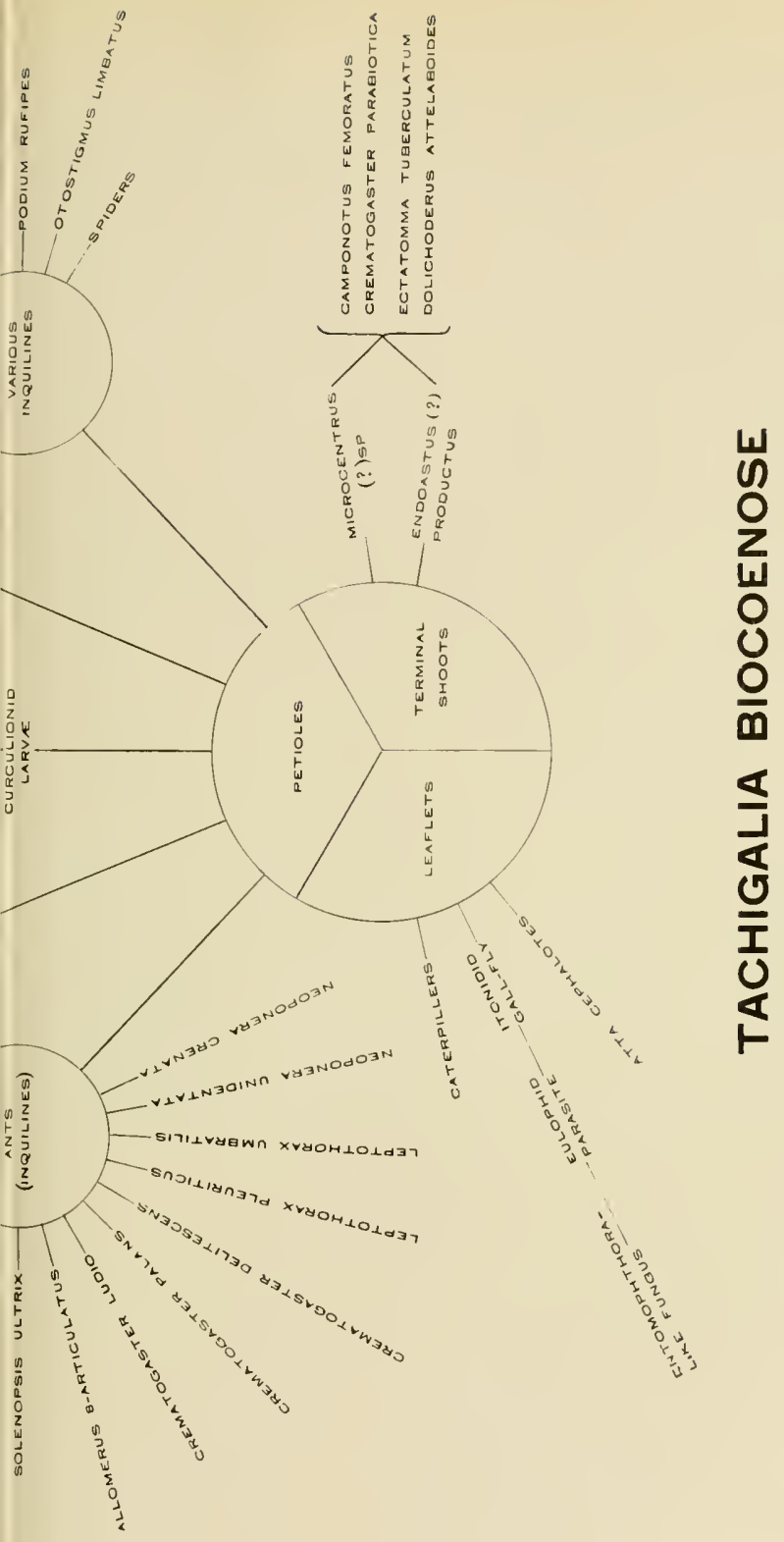





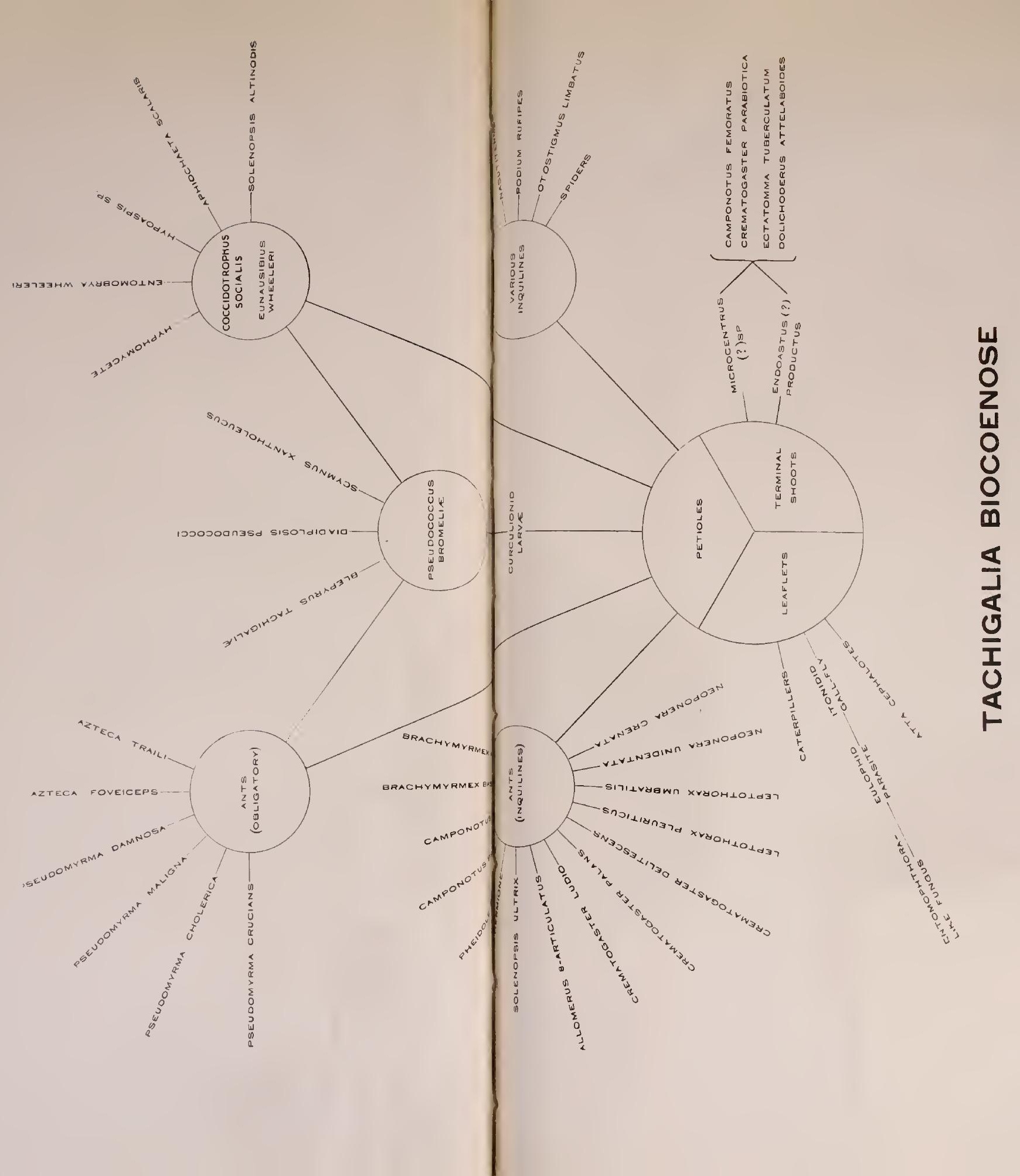




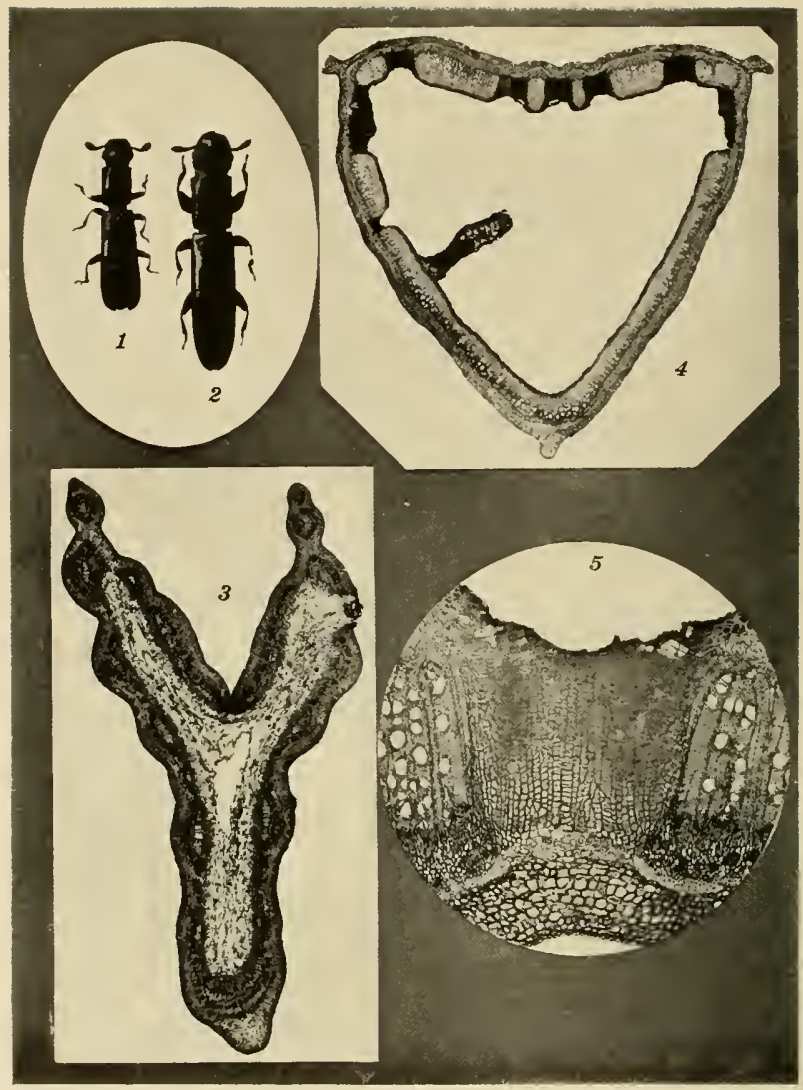

PIAATE III

Fig. 1. Eunausibius uheteri Schwarz and Barber. $\mathrm{X}$. .

Fig. 2. Coccidotrophus social is Sehwarz and Barber. $\mathrm{X} x$

Fig. 3, Cross section of base of very young petiole of adult Tuchiguliu, showing pith still in the eavity. Photograph by Prof. I. W. Bailey.

Vir. 1. Cross section of base of large petiole of Tachigalin inhabited by Pscudomerma cross section or base of large petiole damnosa. The dark areas in the wall are nutritive parenchyma, whe the disturbed by the ants but nourishes their coccids. A portion of one of the

Fig. 5. Cross section through one of the strands of nutritive parenchyma showing the cells with their homogeneous, imher-colored contents. Plotograph by Prof. I. W. Bailey. 


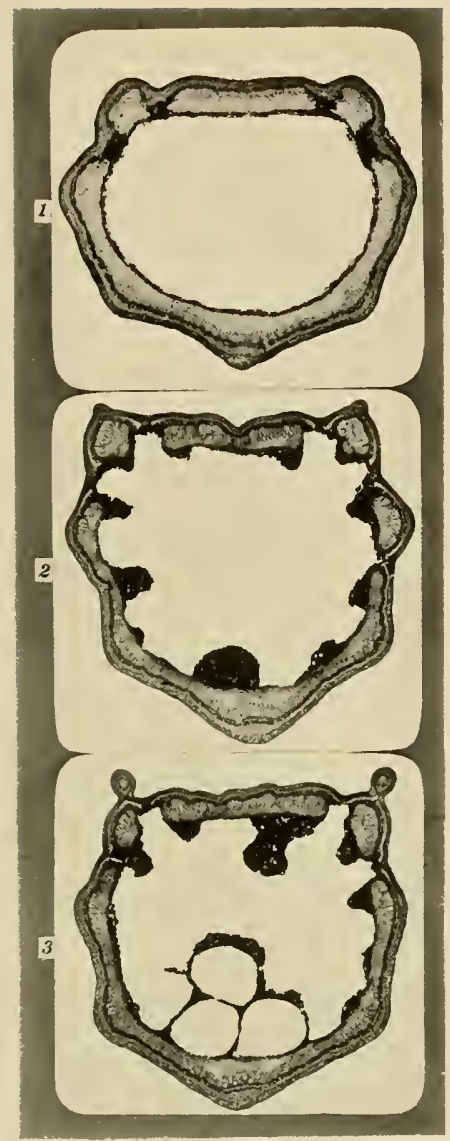

PLATE 1V.

I. iv 1 . Cruss section of an as yet uninhabited petiolar swelling of a youny Tackigalia showing the intact nutritive parenchyma, large pith cavity, and thin layer of pith cells lining it. Photograph by Prof. 1. W. Bailey.

Fic. 2. Cross section of a petiolar swelling inhabited by Coccidotrophus socialis, showing the gnawed nutritive parenchyma and the frass ridges. Photograph by Prof. I. W. Bailey.

Fix. 3. Section similar to that of Fig, 2 but showing three Coccidotrophus cocoons in cross gection. Photograph by Prof I. W Bailey. 

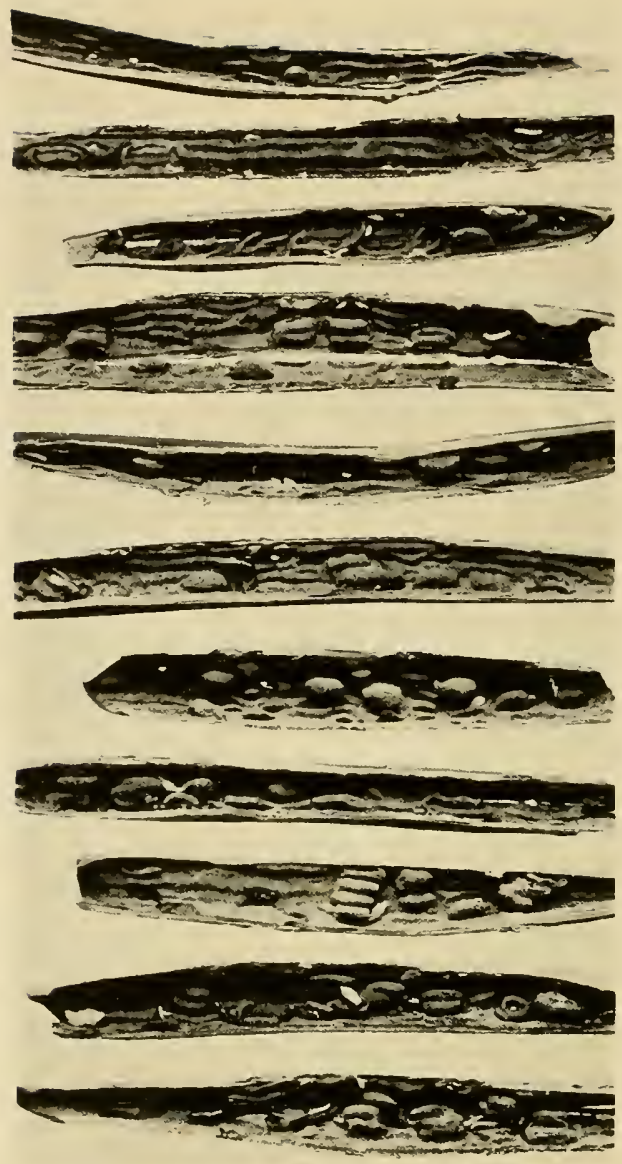

\section{PLATE V.}

Halves of various Tachigalia petioles seen from the inside, showing the arrangements of the cocoons. frass ridges, entrances, and in some eases also the beetles. larre and eoceids "nd a pupa (second figure from below). 






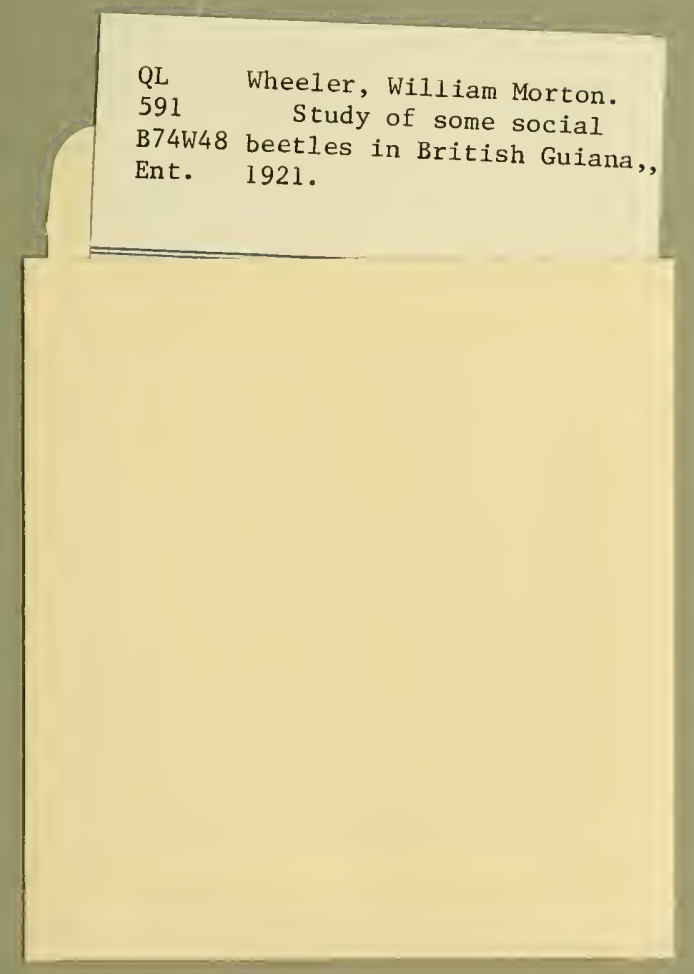


SMITHSONIAN INSTITUTION LIBAARIES

|||||||||||||||||||||||||||||||||||||||||||||||||||||||||||||||||

39088003567518 Study of some social beetles in British 